NBER WORKING PAPER SERIES

\title{
FOR BETTER OR FOR WORSE: \\ DEFAULT EFFECTS AND 401(K) SAVINGS BEHAVIOR
}

\author{
James J. Choi \\ David Laibson \\ Brigitte Madrian \\ Andrew Metrick \\ Working Paper 8651 \\ http://www.nber.org/papers/w8651 \\ NATIONAL BUREAU OF ECONOMIC RESEARCH \\ 1050 Massachusetts Avenue \\ Cambridge, MA 02138 \\ December 2001
}

We thank Hewitt Associates for their help in providing the data. We are particularly grateful to Lori Lucas and Jim McGhee, two of our many contacts at Hewitt. We are also grateful for the comments of James Poterba and other participants at the NBER Economics of Aging Conference held at The Boulders in Carefree, Arizona on May 17-19, 2001. Choi acknowledges financial support from a National Science Foundation Graduate Research Fellowship. Laibson and Madrian acknowledge financial support from the National Institute on Aging (R01-AG-16605 and R29-AG-013020 respectively). Laibson also acknowledges financial support from the MacArthur Foundation. The views expressed herein are those of the authors and not necessarily those of the National Bureau of Economic Research.

(C) 2001 by James J. Choi, David Laibson, Brigitte Madrian and Andrew Metrick. All rights reserved. Short sections of text, not to exceed two paragraphs, may be quoted without explicit permission provided that full credit, including (C) notice, is given to the source. 
For Better or For Worse: Default Effects and 401(k) Savings Behavior James J. Choi, David Laibson, Brigitte Madrian and Andrew Metrick

NBER Working Paper No. 8651

December 2001

JEL No. J320, D120, G110, H000

\begin{abstract}
In the last several years, many employers have decided to automatically enroll their new employees in the company 401(k) plan. Using several years of administrative data from three large firms, we analyze the impact of automatic enrollment on $401(\mathrm{k})$ participation rates, savings behavior, and asset accumulation. We find that although employees can opt out of the $401(\mathrm{k})$ plan, few choose to do so. As a result, automatic enrollment has a dramatic impact on retirement savings behavior: $401(\mathrm{k})$ participation rates at all three firms exceed $85 \%$, but participants tend to anchor at a low default savings rate and in a conservative default investment vehicle. We find that initially, about $80 \%$ of participants accept both the default savings rate ( $2 \%$ or $3 \%$ for our three companies) and the default investment fund (a stable value or money market fund). Even after three years, half of the plan participants subject to automatic enrollment continue to contribute at the default rate and invest their contributions exclusively in the default fund. The effects of automatic enrollment on asset accumulation are not straightforward. While higher participation rates promote wealth accumulation, the low default savings rate and the conservative default investment fund undercut accumulation. In our sample, these two effects are roughly offsetting on average. However, automatic enrollment does increase saving in the lower tail of the savings distribution by dramatically reducing the fraction of employees who do not participate in the 401 (k) plan.
\end{abstract}

James J. Choi

Department of Economics

Harvard University

Littauer Center

Cambridge, MA 02138

james_choi@post.harvard.edu

Brigitte C. Madrian

University of Chicago

Graduate School of Business

1101 E. 58th Street

Chicago, IL 60637

and NBER

brigitte.madrian@gsb.uchicago.edu
David Laibson

Department of Economics

Harvard University

Littauer Center

Cambridge, MA 02138

and NBER

dlaibson@harvard.edu

Andrew Metrick

Department of Finance, 2300 SH-DH

University of Pennsylvania, Wharton School

3620 Locust Walk

Philadelphia, PA 19104

and NBER

metrick@wharton.upenn.edu 


\section{For Better or Worse: Default Effects and 401(k) Savings Behavior}

\section{Introduction}

Seemingly minor changes in the way a choice is framed to a decision-maker can generate dramatic changes in behavior. Automatic enrollment provides a clear example of such effects. Under automatic enrollment (also called negative election), employees are automatically enrolled in their company's 401(k) plan unless the employees elect to opt out of the plan. This contrasts with the usual arrangement in which employees must actively choose to participate in their employer's 401(k).

Standard economic theory predicts that automatic enrollment should not influence the employee's saving decision, since automatic enrollment does not change the economic fundamentals of the planning problem. But several studies and anecdotal accounts suggest that automatic enrollment has succeeded in dramatically increasing 401(k) participation. ${ }^{1}$ For example, Madrian and Shea (2001) document a 48 percentage point increase in 401(k) participation among newly hired employees and an 11 percentage point increase in participation overall at one large U.S. company 15 months after the adoption of automatic enrollment. Madrian and Shea also note that automatic enrollment has been particularly successful at increasing 401(k) participation among those employees least likely to participate in standard retirement savings plans: young, lower-paid, and Black and Hispanic employees.

The U.S. Treasury Department has noted the potential positive impact of automatic enrollment on 401(k) participation rates. The first Treasury Department opinion on this subject, issued in 1998, sanctioned the use of automatic enrollment for newly hired employees. ${ }^{2}$ A second ruling, issued in 2000 , further validated the use of automatic enrollment for previously

\footnotetext{
${ }^{1}$ In addition to Madrian and Shea (2001), see Profit Sharing/401(k) Council of America (2001), Fidelity Institutional Retirement Services Company (2001), and Vanguard (2001).

${ }^{2}$ See IRS Revenue Ruling 98-30 (Internal Revenue Service 1998).
} 
hired employees not yet participating in their employer's 401(k) plan. ${ }^{3}$ In addition, during his tenure as Treasury Secretary, Lawrence H. Summers publicly advocated employer adoption of automatic enrollment. ${ }^{4}$

While automatic enrollment has, by all accounts, increased $401(\mathrm{k})$ participation, this "success" has come at some cost. The employer must choose a default contribution rate and a default fund in which to invest employee contributions. Madrian and Shea show that, at least in the short term, only a small fraction of automatically enrolled 401(k) participants elect a contribution rate and/or asset allocation that differs from the company-specified default. Therefore, low default savings rates and conservative default funds may lower employee wealth accumulation in the long run. A recent Profit Sharing/401(k) Council of America (2001) survey reports that $76 \%$ of automatic enrollment companies have either a $2 \%$ or $3 \%$ default savings rate and that $66 \%$ of automatic enrollment companies have a stable value or money market default fund. These finding are echoed in a report on Vanguard client experiences with automatic enrollment: $73 \%$ have a default contribution rate of $3 \%$ or less, and $53 \%$ have a stable value or money market default fund (Vanguard 2001). If employees stick to such defaults in the long run, they may not accumulate as much retirement wealth as employees in companies without automatic enrollment.

In this paper we evaluate the impact of automatic enrollment over a horizon of up to four years in three different companies. We use data from the company analyzed by Madrian and Shea and extend their analysis to 27 months after the implementation of automatic enrollment. In addition, we analyze data extending to four years after the adoption of automatic enrollment in a second company, and to three years after the adoption of automatic enrollment in a third company.

Based on the Vanguard report and the Profit Sharing/401(k) Council of America survey data summarized above, the three companies that we study have typical automatic enrollment programs. One of our companies has a default contribution rate of $2 \%$ and a stable value default

\footnotetext{
${ }^{3}$ See IRS Revenue Ruling 2000-8 (Internal Revenue Service 2000a). See also Revenue Rulings 2000-33 and 200035 (both Internal Revenue Service 2000b).

${ }^{4}$ See "Remarks of Treasury Secretary Lawrence H. Summers at the Department of Labor Retirement Savings Education Campaign Fifth Anniversary Event" at http://www.ustreas.gov/press/releases/ps785.htm and accompanying supporting documents.
} 
fund; the second has a default contribution rate of $3 \%$ and a stable value default fund; and the third has a default contribution rate of $3 \%$ and a money market default fund.

We find that automatic enrollment has a dramatic impact on participation rates. Under automatic enrollment, 401(k) participation rates exceed $85 \%$ in all three companies regardless of the tenure of the employee. Prior to automatic enrollment, 401(k) participation rates ranged from $26-43 \%$ after six months of tenure at these three firms, and from 57-69\% after three years of tenure.

We also find that automatic enrollment has a large impact on contribution rates and asset allocation choices. Under automatic enrollment, $65-87 \%$ of new plan participants save at the default contribution rate and invest exclusively in the default fund. This percentage declines slowly over time, falling to $40-54 \%$ after two years of tenure, and to about $45 \%$ after three years of tenure (in the two companies for which data extends this far).

Thus, while automatic enrollment encourages 401(k) participation, it at least temporarily anchors participants at a low savings rate and in a conservative investment vehicle. Higher participation rates raise average wealth accumulation, but a low default savings rate and a conservative default investment undercut accumulation.

In our sample, these effects are roughly offsetting. Controlling for income and tenure, we compare total 401(k) balances for employees who joined the firm before automatic enrollment to employees who joined the firm after automatic enrollment. We find that automatic enrollment has little impact on average long-run wealth accumulation. However, this analysis is biased by the fact that the employees hired before the adoption of automatic enrollment had the benefit of a spectacular bull market, while those hired after automatic enrollment experienced a period of relatively flat equity performance.

To eliminate these equity-market effects we compare the average 401(k) contribution rates of the cohorts hired before automatic enrollment to the average contribution rates of the cohorts hired after automatic enrollment. These average contribution rates include participants and non-participants (who have a zero contribution rate). For our companies we find that automatic enrollment has a modest positive effect on average contribution rates.

Although automatic enrollment does not have a dramatic impact on average 401(k) balances or contribution rates, automatic enrollment does have a large impact on the distribution of balances. The high participation rate resulting from automatic enrollment drastically reduces 
the fraction of employees with zero balances, thereby thinning out the bottom tail of the distribution of employee balances. In addition, the effect of automatic enrollment in anchoring employees at low savings rates and in conservative investments shrinks the upper tail of the distribution of balances. Hence, automatic enrollment reduces the variance of wealth accumulation across all employees.

The rest of this paper substantiates these claims and discusses their policy implications. In Section II we provide background information on the three firms that we study. In Section III we discuss the impact of automatic enrollment on 401(k) participation rates. In Section IV we analyze the impact on contribution rates and asset allocation. In Section V we discuss the impact on balance accumulation. We conclude in Section VI by discussing ways that automatic enrollment can be used to promote both higher participation rates and higher rates of asset accumulation. In the conclusion we also acknowledge the important normative questions raised by this research—whether employees are necessarily made better off when they are coaxed into saving more through automatic enrollment.

\section{401(k) Automatic Enrollment in Three Large Companies}

We consider the experience of automatic enrollment in three large U.S. corporations. Table 1 compares these companies. Company A is an office equipment company with approximately 32,000 employees; Company B is the health services firm analyzed in Madrian and Shea and has approximately 30,000 employees; and Company $\mathrm{C}$ is a food products company that has approximately 18,000 employees in the U.S. In all three companies, the 401(k) plan is the only retirement savings plan available to employees. At Company $\mathrm{C}$, however, there are three different 401(k) plans that apply to different groups of employees. We consider only the largest plan that is available to about 13,000 employees.

In Company A, automatic enrollment was implemented on January 1, 1997 for all new hires. As noted previously, the default contribution rate at Company A is $2 \%$, and the default investment fund is a stable value fund. No other changes to the 401(k) plan at Company A were made concurrent with the adoption of automatic enrollment.

In Company B, automatic enrollment was implemented on April 1, 1998 for all new hires. The default contribution rate at this company is $3 \%$, and the default investment fund is a money market fund. Concurrent with the switch to automatic enrollment, Company B also 
eliminated a one-year length-of-service requirement. All employees at Company B who had not satisfied this length-of-service requirement on April 1, 1998 became immediately eligible to participate in the 401(k) plan, although they were not subject to automatic enrollment. Our analysis of Company B accounts for this change in eligibility by only analyzing the behavior of employees who are eligible for the $401(\mathrm{k})$ plan at the time of observation. ${ }^{5}$

Company C first implemented automatic enrollment on January 1, 1998 for all new hires. As with Company B, Company $\mathrm{C}$ also eliminated a one-year length-of-service requirement that applied to employees under the age of $40 .^{6}$ Employees under the age of 40 who had not satisfied the length-of-service requirement on January 1, 1998 became immediately eligible to participate in the $401(\mathrm{k})$ plan, but in contrast to Company B, these employees were subject to automatic enrollment along with the new hires at Company C. In addition, on November 1, 1999, Company C applied automatic enrollment to all employees hired before January 1, 1998 who were eligible to participate in the 401(k) plan at that time but who had not yet participated as of November 1, 1999. ${ }^{7}$ The default contribution rate at Company $\mathrm{C}$ is $3 \%$, and the default investment is a stable value fund. Because of the eligibility changes for employees under the age of 40 that occurred at Company $\mathrm{C}$ concurrent with the adoption of automatic enrollment, we restrict our analysis at Company $\mathrm{C}$ to employees who were aged 40 and above at the time of hire and who thus were immediately eligible to participate in the 401(k) plan both before and after the initial implementation of automatic enrollment.

In our empirical analysis, we distinguish between "employees hired before automatic enrollment" and "employees hired after automatic enrollment." In Companies A and B "employees hired before automatic enrollment" were never subject to automatic enrollment since automatic enrollment only affected new hires. By contrast, in Company C, "employees hired before automatic enrollment" who failed to join the 401(k) plan were eventually subject to automatic enrollment. ${ }^{8}$ For this reason, we make an additional distinction for the employees of

\footnotetext{
${ }^{5}$ Madrian and Shea analyze the effects of the eligibility changes on participation in Company B. They find that eligibility rules do not substantively affect participation rates (outside of the non-eligibility period).

${ }^{6}$ Prior to January 1, 1998, employees in Company C became eligible for the 401(k) plan after one year of employment or on their $40^{\text {th }}$ birthday, whichever came first.

${ }^{7}$ The group of employees subject to this second round of automatic enrollment at Company C included all those hired through the end of 1996 and employees hired during 1997 who were 40 years old or more on December 31, 1997.

${ }^{8}$ Specifically, employees hired before January 1, 1998 who were 40 years old or older on December 31, 1997 were subject to automatic enrollment on November 1, 1999.
} 
Company C. We distinguish between "employees hired before automatic enrollment and observed before automatic enrollment" and "employees hired before automatic enrollment and observed after automatic enrollment." Note that the same employee can appear in the former category and later also be observed in the latter category.

For Company A, we have administrative data on all active employees from three yearend cross-sectional snapshots for 1998, 1999 and 2000. In Company C we also have administrative data from three year-end cross-sectional snapshots, although the 1998 and 1999 data only includes employees who are active 401(k) participants, while the 2000 data includes all active employees, both participants and non-participants. For both Companies A and $\mathrm{C}$ the data contain basic administrative items such as hire date, birth date, gender, and pay. The data also include variables that capture several important aspects of 401(k) participation, such as the date of initial participation, current participation status, and an individual's current contribution rate and investment allocation. In addition, we have information on former employees who continue to hold positive account balances with their former employer.

For Company B we have ten cross-sectional snapshots: June 1, 1997, and month-end data for December 1997; June and December of 1998; March, June, September, and December of 1999; and March and June of 2000. The data elements include substantively all of the same elements available for Company A, with the exception that we do not have the date of initial 401(k) participation, only 401(k) participation at the time of each cross-section.

Note that for Companies A and C, all of the data was collected subsequent to the adoption of automatic enrollment. We can, however, observe the historical participation behavior of employees hired prior to automatic enrollment using the date of original plan participation. In Company B, although we do not have information on the initial date of 401(k) participation, we do have two cross-sections that were collected before the implementation of automatic enrollment. We can thus examine the impact of automatic enrollment on 401(k) participation and savings behavior by comparing the outcomes for employees in these two preautomatic enrollment cross-sections with the outcomes for employees hired after automatic enrollment in the later cross-sections.

In all three companies, we place some restrictions on the employees actually used in the analysis. In Company A, we exclude all employees hired before October 1995. This restriction is motivated by the consolidation in October 1995 of three different retirement savings plans into 
one. In Companies B and C, we exclude all employees hired before 1995 from the sample simply to keep the composition of employees in these three companies roughly comparable. In Company B, we also exclude all individuals who became employees by virtue of several large and small acquisitions undertaken by the company between 1995 and the last round of data collection. And, as previously noted, in Company $\mathrm{C}$ we exclude all employees under the age of 40 at the time of hire.

\section{The Effect of Automatic Enrollment on 401(k) Participation}

In this section we examine the effects of automatic enrollment on 401(k) participation. We begin in Figure 1 by plotting the relationship between tenure and 401(k) participation. Note that because of differences in the type of data available on 401(k) participation in the three companies, the measure of 401(k) participation differs across these companies. For Companies $\mathrm{A}$ and $\mathrm{C}$, Figures 1A and 1C show the relationship between tenure and ever having participated in the 401(k) plan. For Company B, Figure 1B shows actual point-in-time participation rates. ${ }^{9}$ The black bars show the tenure-participation profile of employees hired prior to automatic enrollment, while the gray bars show that of employees hired subsequent to automatic enrollment.

We first look at Company A. For employees hired prior to automatic enrollment, 401(k) participation starts out low, increases quite rapidly during the first few months of employment, and continues to increase at a slower pace after that. At 48 months of employment, the participation rate reaches about 70\%. 401(k) participation also starts out low for employees hired under automatic enrollment and then increases very rapidly during the third and fourth months of employment. The jump in Company A arises because there is a 60-day opt-out period between the hire date and the automatic enrollment date. Moreover, in practice it appears to take somewhat longer than 60 days for newly hired employees who do not opt out to be automatically enrolled. After the participation jumps in months three and four, the participation rate levels off at around $92 \%$ in month five. Between the $5^{\text {th }}$ and $36^{\text {th }}$ months of employment, there is a further increase from $92 \%$ to almost $98 \%$ of employees having ever participated. This increase is driven

\footnotetext{
${ }^{9}$ The participation profiles in Figure 1B exhibit more variability than those in Figure 1A because the profiles for Company B are primarily identified off of cross-sectional variation in the participation rate of individuals with (continued on next page)
} 
by two factors. First, some employees who initially opted out of 401(k) participation eventually elect to participate. Second, employees who opt out of 401(k) participation have a slightly higher turnover rate than those enrolled in the plan, so that as tenure increases the sample of employees used to calculate the participation rate is increasingly composed of individuals who did not choose to opt out.

The effect of automatic enrollment on having ever participated in the 401(k) plan is the difference between the two sets of bars in Figure 1A. This difference is plotted in Figure 2A. Note that during the first two months of employment, automatic enrollment actually reduces the 401(k) participation rate by 2-3 percentage points. We attribute this to individuals deciding not to proactively enroll during the first two months of employment because they know that they will be automatically enrolled in the near future anyway. The effect of automatic enrollment on 401(k) participation peaks around 5 months of employment at almost 70 percentage points. After 5 months of employment, the participation rate of employees hired under automatic enrollment increases at only a very small rate each month while that of employees hired before automatic enrollment increases more rapidly. As a result, the effect of automatic enrollment on the 401(k) participation rate slowly decreases after month five. Even so, after 48 months, the fraction of employees having ever participated in the $401(\mathrm{k})$ plan is still 28 percentage points higher for employees hired after automatic enrollment than for employees hired before automatic enrollment.

Figures $1 \mathrm{~B}$ and $2 \mathrm{~B}$ show similar patterns for Company B. For the analysis of Company B, we control for Company B's change in 401(k) eligibility rules by only using observations from employees who are eligible at the time of observation. This restriction eliminates variation in participation due to variation in eligibility rules. As in Company A, the 401(k) participation rate of employees hired before automatic enrollment starts out low and increases steadily until it reaches $58 \%$ at 36 months of tenure. ${ }^{10}$ In contrast, for employees hired under automatic enrollment, the 401(k) participation rate starts out high, at about $86 \%$, and remains high, increasing only slightly, up to about $88 \%$ after two years. The higher initial participation rates in

different amounts of tenure. In contrast, the profiles in Figure 1A reflect longitudinal data on individual employees since we know the date at which each employee of Company A first enrolled in the 401(k) plan.

${ }^{10}$ For this company, the 401(k) participation rate of employees hired before automatic enrollment is not observed until the $4^{\text {th }}$ month of employment (taken from the June 1998 cross section). Earlier cross-sections only contain information about employees who were not eligible to participate during their first year of employment. 
Company B relative to Company A result from a shorter automatic enrollment delay period (60 days in Company A vs. 30 days in Company B), and from quicker enrollment of individuals once the opt-out period has ended. As in Company A, the effect of automatic enrollment on 401(k) participation is highest during the $5^{\text {th }}$ month of employment, where it reaches 60 percentage points. By the $27^{\text {th }}$ month of employment, the effect has fallen quite substantially, but remains sizeable at 33 percentage points (Figure 2B). Because the last Company B cross-section is in June 2000 and automatic enrollment was introduced in April 1998, we have no post-automatic enrollment data beyond 27 months for this company.

In Company $\mathrm{C}$, we look at the effect of automatic enrollment on employees "hired after automatic enrollment," as in Companies A and B, and on employees who became subject to automatic enrollment during their tenure at the company, those "hired before automatic enrollment and observed after automatic enrollment." This second group can only be observed at Company $\mathrm{C}$ since this is the only company that applied automatic enrollment to previously hired employees. Figure 1C, which we turn to next, profiles the effect of automatic enrollment on the participation rates of employees who were hired under the automatic enrollment regime. Figure 1D documents the effect of automatic enrollment on employees who were hired before automatic enrollment was put in place, but who subsequently became subject to automatic enrollment. Note that by the time automatic enrollment was applied to this latter group of employees, they all had at least 23 months of tenure at the company.

In Figure 1C, the black bars plot the 401(k) participation rates for employees "hired before automatic enrollment and observed before automatic enrollment" (i.e, observed prior to the point in time when they became subject to automatic enrollment if not already participating). ${ }^{11}$ These pre-automatic enrollment participation rates start out low and increase with tenure. This pattern roughly matches the patterns observed in Companies A and B. At 36 months of tenure, the $401(\mathrm{k})$ participation rate for these pre-automatic enrollment employees is about 69\%. Figure 1C compares this profile with the participation profile of employees who were subject to automatic enrollment upon hire. Their 401(k) participation rate increases quite dramatically in the first two months of employment, and reaches $92 \%$ at three months of tenure, increasing only slightly thereafter. 
In Figure 1D the black bars are the same as those in Figure 1C (plotting the participation rate for employees "hired before automatic enrollment and observed before automatic enrollment"). The white bars represent employees who were hired before automatic enrollment was adopted, but uses data for these employees at tenure levels after they became subject to automatic enrollment: those "hired before automatic enrollment and observed after automatic enrollment."12 Figure 1D shows that automatic enrollment has a dramatic effect on the participation rate of these employees as well. At 36 months of employment, the participation rate for this group is $96 \%$.

Figure 2C shows the impact of automatic enrollment on the $401(\mathrm{k})$ participation rates by tenure for both groups of employees subject to automatic enrollment in Company $\mathrm{C}$ : those "hired after automatic enrollment" and those "hired before automatic enrollment and observed after automatic enrollment". ${ }^{13}$ As in Companies A and B, the effect of automatic enrollment on 401(k) participation is large initially and declines over time. In Figure $2 \mathrm{C}$ we also see that automatic enrollment is slightly more effective at increasing 401(k) participation for new hires (i.e., those "hired after automatic enrollment") than for old hires (i.e., those "hired before automatic enrollment and observed after automatic enrollment"). One explanation for the slightly higher participation rates under automatic enrollment for new vs. old hires is that oldhires may have become accustomed to a certain level of take-home pay and are thus more likely to opt out of 401(k) participation in order to avoid a decrease in their level of consumption.

\section{The Effect of Automatic Enrollment on Contribution Rates and Asset Allocation}

We now turn to the effect of automatic enrollment on the savings behavior of 401(k) participants. In their study of automatic enrollment, Madrian and Shea show that in the short run, 401(k) participants hired under automatic enrollment are very likely to passively accept the default contribution rate and fund allocation. In this section of the paper, we document the persistence of this type of default savings behavior over longer periods of time. We first

\footnotetext{
${ }^{11}$ Specifically, these employees include those hired during or before 1997 for tenures that take these employees up to November 1999, when automatic enrollment was applied to these employees.

12 Specifically, the white bars include employees hired during or before 1997 for tenures beginning in December 1999, when automatic enrollment became effective for these employees.

${ }^{13}$ The bars in this graph are formed by differencing the bars within Figure 1C - this generates the gray "hired after automatic enrollment" effect—and differencing the bars within Figure 1D—this generates the black "hired before automatic enrollment and observed after automatic enrollment" effect.
} 
document the effects of automatic enrollment on $401(\mathrm{k})$ contribution rates. Figures $3 \mathrm{~A}, 3 \mathrm{~B}$, and $3 \mathrm{C}$ compare the distribution of contribution rates for $401(\mathrm{k})$ participants who are subject to automatic enrollment to participants who are not subject to automatic enrollment. For all three companies, employees are classified as participants if they have a non-zero contribution rate at the time of the data collection. Within each company we compare employees with similar months of on-the-job tenure to eliminate the possibility that differences in tenure drive our automatic enrollment effects. Because of differences in our underlying data sources and in the timing of automatic enrollment adoption, the tenure controls vary for each company.

Figure $3 \mathrm{~A}$ plots the distribution of 401(k) contribution rates for participating employees in Company A with 24-35 months of tenure since their hire date. It compares the employees who were "hired before automatic enrollment" to the employees who were "hired after automatic enrollment." (Recall that in Companies A and B automatic enrollment was only applied to new employees.) Figure 3B plots the distribution of 401(k) contribution rates for participating employees in Company B with 0-23 months of tenure since their hire date. Like Figure 3A, Figure 3B also compares the employees who were "hired before automatic enrollment" to the employees who were "hired after automatic enrollment." Figure 3C plots the distribution of 401(k) contribution rates for participating employees in Company $\mathrm{C}$ with 12-35 months of tenure since their hire date. It compares the employees who were "hired before automatic enrollment and observed before automatic enrollment" (the control group for Company C) to employees who were "hired after automatic enrollment."

These histograms show a striking difference between the contribution rates of 401(k) participants who were subject to automatic enrollment and those who were not. The modal contribution rate of participants hired before automatic enrollment in all three companies is $6 \%$, the point after which employer matching contributions cease (see Table 1). In contrast, for employees hired under automatic enrollment, the modal contribution rate is the automatic enrollment default: $2 \%$ in Company A and 3\% in Companies B and C. For all three of our companies, the fraction of participants at the default contribution rate increases at least 30 percentage points as a result of automatic enrollment. In Company A, the fraction of participants at the default contribution rate increases from $21 \%$ to $57 \%$. In Company $\mathrm{B}$, the fraction of participants at the default contribution rate increases from $7 \%$ to $72 \%$. In Company $\mathrm{C}$, the fraction of participants at the default contribution rate increases from $12 \%$ to $46 \%$. 
Madrian and Shea show that for low-tenure employees, this shift in the modal contribution rate to the automatic enrollment default for employees hired subsequent to automatic enrollment is driven both by a movement from a $0 \%$ contribution rate (nonparticipation) to the default contribution rate and by a movement from higher contribution rates to the default. In Table 2, we examine the effect of automatic enrollment on the distribution of contribution rates in Companies A and B by tenure to determine whether passive acceptance of the default savings rate persists over time. ${ }^{14}$ To evaluate the extent to which the pronounced mass of participants at the default contribution rate is driven by the induced participation of would-be non-participants, we also include non-participation as one of the contribution rate categories. The non-zero contribution rates are aggregated into three broad categories: the automatic enrollment default contribution rate, contribution rates less than the default $(<$ Default), and contribution rates greater than the default (> Default).

In Company A, we can combine multiple cross-sections to obtain the distribution of contribution rates for employees hired both before and after automatic enrollment for employees with 2-4 years of tenure. In addition, we can calculate the distribution of contribution rates for employees hired after automatic enrollment with lower levels of tenure. Looking first at employees hired under automatic enrollment, we see that after 6 months of employment, the fraction of employees who are non-participants is fairly constant at about $8 \%$. The fraction of employees with a contribution rate in excess of the default, however, increases quite steadily with tenure, while the fraction of employees contributing at the default declines. For employees with 24-29 months of tenure, the fraction of employees hired under automatic enrollment with a contribution rate exceeding the default is $36 \%$, compared to $39 \%$ for employees hired before automatic enrollment. At 42-47 months of tenure, the fraction of employees with a contribution rate exceeding the default is $44 \%$ for those hired under automatic enrollment and $53 \%$ for those hired before automatic enrollment. That the fraction of employees contributing at a rate higher than the default is larger for those hired before automatic enrollment than for those hired after suggests that, even after four years, some of the participants who contribute at the default rate would have chosen a higher contribution rate had they not been subject to automatic enrollment.

\footnotetext{
${ }^{14}$ We are precluded from including Company $\mathrm{C}$ in this analysis and the analysis in Table 3 because we have only one cross-sectional dataset for this company that includes both 401(k) participants and non-participants.
} 
For Company B we have overlapping tenure data for employees hired before and after automatic enrollment with three or more months of tenure. As with Company A, the fraction of non-participants among those hired after automatic enrollment is fairly constant at about 12-13\% for all tenure levels. And, similar to Company A, the fraction of employees hired under automatic enrollment with a contribution rate exceeding the default increases with tenure, while the fraction contributing at the default declines. In Company B, however, similar fractions of employees hired both before and after automatic enrollment have contribution rates exceeding the default after 12 months of tenure. Thus, after one year, the substantial mass of participants at the automatic enrollment default contribution rate in Company B appears to result largely from a conversion of non-participants into participants at the default rate.

We next consider how the automatic enrollment default affects investment allocations. We begin with Table 3, which is similar in spirit to Table 2 but shows the fraction of employees who are non-participants, participants invested wholly in the default fund, participants with some other investment allocation, and participants with no balances. This last category is omitted for Company B because in the Company B data there are only a handful of individuals in each tenure category who are participants with no balances. At all tenure levels in both companies, the fraction of employees wholly invested in the automatic enrollment default fund is very large for employees hired after automatic enrollment and much smaller for employees hired before automatic enrollment. In both companies we also see that the fraction of employees hired under automatic enrollment with a $100 \%$ default fund asset allocation decreases with tenure. For employees hired prior to automatic enrollment, there is no discernable tenure-based trend in the fraction of employees at the automatic enrollment default. When we compare employees hired before and after automatic enrollment with similar levels of tenure, the fraction with a nondefault asset allocation is higher for those hired before automatic enrollment at all levels of tenure in both companies. Thus, under automatic enrollment, the group of employees who are wholly invested in the default fund is comprised both of employees who would have been nonparticipants in the absence of automatic enrollment and of employees who would have participated but with a different allocation of funds.

Figure 4 plots the relationship between tenure and three different measures of default savings behavior: 1) the fraction of participants contributing at the default contribution rate and investing exclusively in the default fund (the black lines); 2) the fraction of participants 
contributing at the default contribution rate and investing with a non-default investment allocation (the dashed lines); and 3) the fraction of participants contributing at a non-default contribution rate and investing exclusively in the default fund (the gray lines). We calculate these percentages for 401(k) participants who were and were not subject to automatic enrollment. The thin lines represent the fraction of participants hired prior to automatic enrollment (and, in the case of Company $\mathrm{C}$, include only periods in which these employees were not yet subject to automatic enrollment). The thick lines represent the fraction of employees hired after automatic enrollment.

In Company A, all three measures of default savings behavior increase rapidly over the first three months of employment. This increase reflects the fact that it takes five months for automatic enrollment to fully take effect in Company A. Individuals hired after automatic enrollment who show up in the data as participants in their first three months of employment are primarily comprised of individuals who initiated 401(k) participation before the end of the automatic enrollment opt-out period. Not having been automatically enrolled, these individuals are also not very likely to have either the automatic enrollment default contribution rate or the automatic enrollment default asset allocation. The fraction of participants who are at the default for each of these measures peaks in the $5^{\text {th }}$ month of employment, as does the effect of automatic enrollment on participation in Figure 2A. For Company $\mathrm{C}$ the initial increase in the fraction of employees at the various default measures is much less pronounced than in Company A because the opt-out period in this company is shorter. For Company B there is no initial increase in the fraction of employees at the various measures of the default because by the time individuals are observed in this company's data, the opt-out period has already ended. In all three companies, the fraction of employees at any of these default measures declines substantially with tenure. However, even at high levels of tenure, a large fraction of employees remain at the automatic enrollment default. In Company A, 38\% of participants hired under automatic enrollment are at both the default rate and wholly invested in the default fund after four years. In Company B, this fraction is 39\% after 27 months, and in Company $\mathrm{C}$ it is 50\% after three years. (Note, however, that in Company $\mathrm{C}$ there is much more variability in the fraction of employees at the various defaults with respect to tenure than at the other two companies as a result of the much smaller sample sizes underlying the analysis in Company C). 
Madrian and Shea also show that in a cross-section of employees hired under automatic enrollment in Company B, there are significant differences across demographic groups in the fraction of employees who passively accept both the default contribution rate and the default investment fund. To examine whether demographic characteristics affect the persistence of default savings behavior over time as well, we estimate linear probability regressions for the likelihood that 401(k) participants exhibit these three different types of default savings behavior as a function of tenure (in months), gender, age, compensation, and an interaction between tenure and these three other factors. ${ }^{15}$ In all three companies, the sample of employees used in these regressions is comprised of $401(\mathrm{k})$ participants hired after automatic enrollment. These samples are constructed from the pooled cross-sectional data. ${ }^{16}$ For Company $\mathrm{C}$, we also include separate regression results for participants who were hired before the adoption of automatic enrollment but who did not join the 401(k) plan until after they became subject to automatic enrollment: those "hired before automatic enrollment but first participated after automatic enrollment." The identification in these regressions comes both from variation by tenure within a cross-section in the fraction of participants exhibiting default savings behavior and from variation over time as individuals in multiple cross-sections accumulate more tenure. The coefficients from these regressions are reported in Table 4. The standard errors, reported in parentheses, are corrected for the potential of having more than one observation on the same individual at different points in time.

Consistent with the findings in Madrian and Shea, the initial fraction of participants at the default varies quite significantly with demographic characteristics. Women are slightly (2-4\%) more likely to be at the default than are men in many of the regressions for Companies A and B, but there is little significant effect of being female for either group of participants in Company C.

Relative to employees in the top third of the pay distribution, employees in the bottom and middle of the pay distribution are much more likely to be at the default. ${ }^{17}$ For Company A, employees in the bottom third of the distribution are 30-33\% more likely to be at the default,

\footnotetext{
${ }^{15}$ We report linear probability regressions because the coefficients are readily interpretable. The qualitative nature of the results is very similar under a probit specification.

${ }^{16}$ In Company A, we further restrict the sample to participants with four or more months of tenure. This restriction coincides with Company A's automatic enrollment implementation delay (see Figure 1A).

${ }^{17}$ The position in the pay distribution for each individual is calculated relative to other employees hired in the same month. This pay category is calculated in the first month of employment and does not vary over time for individuals who appear in more than one cross-section.
} 
while those in the middle third are about 16-17\% more likely to be at the default. In Company B, the lowest paid employees are 19-24\% more likely to be at the default, while middle paid employees are 16-20\% more likely to be at the default. In Company C, the effect of compensation on being at the automatic enrollment defaults differs for employees "hired after automatic enrollment" relative to employees "hired before automatic enrollment but [who] first participated after automatic enrollment." For the first group, the lowest paid employees are 50$55 \%$ more likely to be at the default, while middle paid employees are $20-22 \%$ more likely to be at the default. The effects of compensation for employees "hired before AE but [who] first participated after AE" stand in market contrast to those for newly hired employees at all three companies: there is no statistically significant difference between being at the automatic enrollment defaults for the middle and highest paid employees, while the lowest paid employees are actually slightly less likely to be to be at the automatic enrollment defaults.

As with the effects of compensation on being at the default for employees hired after automatic enrollment, age is also negatively related to the initial likelihood of being at the default. Relative to employees over the age of 45, those under the age of 30 are $11-13 \%$ more likely to be at the default in Company A and 3-4\% more likely to be at the default in Company B. Those aged 30-44 are 5-6\% more likely to be at the default in Company A, 6-9\% more likely to be at the default in Company $\mathrm{C}$ (for both groups of employees) ${ }^{18}$, while there is no differential effect for this age group in Company B.

In all three companies, tenure is negatively related to the fraction of participants at the defaults. Looking across the three default measures, the tenure effect is much smaller on being invested wholly in the default fund than on being at the default contribution rate. This suggests that there is more persistence in the default fund allocation than in the default contribution rate. The magnitudes of the tenure coefficients are much larger at Company B than at Companies A and $\mathrm{C}$, implying that there is more persistence in the automatic enrollment defaults at Company $\mathrm{A}$ and $\mathrm{C}$ than at Company B. In Company $\mathrm{B}$, the fraction of participants hired after automatic enrollment at the combined default (column 4) falls by 2.7 percentage points with each additional month of tenure. In Companies $\mathrm{A}$ and $\mathrm{C}$, on the other hand, the fraction of participants at the combined default (column 1 of Tables $4 \mathrm{~A}$ and $4 \mathrm{~B}$ respectively) falls by only 
0.6 (Company A) and 0.9 (Company C) percentage points with each additional month of tenure. Looking at the two groups of participants in Company $\mathrm{C}$, there is less sensitivity to tenure in the automatic enrollment defaults for employees "hired before AE but [who] first participated after AE" than for employees hired after automatic enrollment. As just noted, the fraction of participants at the combined default falls by 0.9 percentage points with each additional month of tenure for employees hired after automatic enrollment at Company $\mathrm{C}$, and by a much smaller 0.2 percentage points with each month of tenure for employees "hired before AE but [who] first participated after AE."

Overall, it appears that compensation and tenure (and to a lesser extent age) are the key determinants of the fraction of employees at the default. Lower paid participants are much more likely to be at the default than are higher paid participants, and the fraction of participants at the default is more persistent for the lower paid. These patterns are consistent with a number of stories. To the extent that pay proxies for human capital, more highly paid employees may be better able to make informed savings decisions, and thus move away from the defaults more quickly. The cost of having the "wrong" contribution rate and asset allocation is also likely to be greater for the more highly paid, who face higher marginal tax rates and hence stronger incentives to take advantage of tax deferred investment opportunities. In addition, high-income employees may have lower rates of time preference, raising their incentives to adopt high saving rates. However, high-income employees also have steeper income profiles, lowering their saving incentives when young.

\section{Automatic Enrollment and Asset Accumulation}

We now turn to the effect of automatic enrollment on overall asset accumulation, which is ultimately the measure that we care most about. The effects of automatic enrollment on asset accumulation are ambiguous. To the extent that automatic enrollment leads to increased or earlier 401(k) participation, automatic enrollment will tend to increase asset accumulation. However, to the extent that default elections under automatic enrollment result in a lower contribution rate than individuals would have otherwise chosen, or a more conservative asset allocation, automatic enrollment will tend to decrease asset accumulation. The negative effect of

\footnotetext{
${ }^{18}$ Note that because the sample in Company $\mathrm{C}$ is restricted to those aged $40+$, this group is actually comprised only (continued on next page)
} 
conservative portfolio choices would have been particularly important during the last decade when stock returns were high.

To examine the effect of automatic enrollment on asset accumulation, we look at the 401(k) balance-to-pay ratio in Companies A and B. ${ }^{19}$ The numerator of this ratio is simply the total 401(k) balances of an individual at a point in time. The numerator includes employer matching contributions and also incorporates the negative effects of employee 401(k) borrowing. In Company A, we exclude the value of balances rolled into the plan (presumably from a previous employer). In practice, very few employees have such balances, but they can be quite large for the employees who have them and greatly increase the variability in average measures of the balance-to-pay ratio. In Company B, the data do not include a separate measure of balances rolled into the plan, so the measure of total balances includes all balances regardless of their source. The denominator of the balance-to-pay ratio is annualized total compensation. For non-participants, the balance-to-pay ratio will generally be zero, with the exception of current non-participants who participated at some point in the past and have consequently accumulated some 401(k) balances. Because we are interested in total 401(k) asset accumulation and not just asset accumulation conditional on participation, we include non-participants in our analysis of asset accumulation.

Figure 5 shows the relationship between tenure since eligibility and the average 401(k) balance-to-pay ratio calculated across all employees, including non-participants. For employees hired after automatic enrollment in Company B (and for all employees in Company A), months since eligibility and total months of tenure are the same. For employees hired before automatic enrollment, these two measures are different. This is because Company B eliminated a one-year length-of-service requirement concurrent with the adoption of automatic enrollment. Asset accumulation is clearly only a relevant measure over the period for which individuals are eligible to contribute to the 401(k) plan. Hence, the measure of time that we use for this analysis is the months since $401(\mathrm{k})$ eligibility. The data used in constructing Figure 5 are the pooled crosssectional data from each company. The identification in these graphs thus comes from both

\footnotetext{
of those aged $40-44$.

${ }^{19}$ We are precluded from including Company $\mathrm{C}$ in this analysis because we have only one cross-sectional dataset for this company that includes both 401(k) participants and non-participants.
} 
variation by tenure within a cross-section and from variation over time as individuals in multiple cross-sections accumulate more tenure.

In both companies, the average balance-to-pay ratio starts out close to zero and increases steadily over time. The increase in the balance-to-pay ratio with tenure appears fairly linear in both companies, as would be expected when balances are low and most of the increase in value comes from additional savings contributions. In Company A, the balance-to-pay ratio for employees hired after automatic enrollment is above that for employees hired prior to automatic enrollment for tenures up to about 42 months, at which point the curves start to intersect each other. In contrast, in Company B, the balance-to-pay ratio is virtually identical for employees hired before and after automatic enrollment with the same length of eligibility.

These average balance-to-pay ratios mask considerable heterogeneity, however, in the distributional effects of automatic enrollment on asset accumulation. In Figure 6, we plot the balance-to-pay ratio for employees at the $25^{\text {th }}, 50^{\text {th }}, 75^{\text {th }}$, and $90^{\text {th }}$ percentiles of the balance-topay distribution both before and after automatic enrollment. In both companies, the very low 401(k) participation rates prior to automatic enrollment are reflected in the zero balance-to-pay ratios of employees in the $25^{\text {th }}$ percentile of the balance-to-pay distribution. For these employees, automatic enrollment clearly increases asset accumulation because it turns nonparticipants into participants.

As suggested in Tables 2 and 3, among those hired after automatic enrollment, the individuals at the $25^{\text {th }}$ percentile of the balance-to-pay distribution are primarily contributing at their respective company's default contribution rates and have their money invested almost entirely in the conservative default funds. For example, an employee who was automatically enrolled during her fourth month of tenure in Company A would accumulate $2 \%$ of her paycheck in a stable value fund each month. If we assume that the return on her stable value account is roughly equal to the rate of growth in her nominal earnings, this worker would have a balanceto-pay ratio of $(2 \%)(9 / 12+11 / 12)(1.67)=5.6 \%$ at the beginning of her $24^{\text {th }}$ month at Company A. The factor of 1.67 reflects the employer matching rate of $67 \%$ at Company A (on the first $6 \%$ of pay). The predicted accumulation level of $5.6 \%$ of earnings is close to the empirical accumulation level of $4.3 \%$ (at the $25^{\text {th }}$ percentile of the balance-to-pay distribution). The slight discrepancy may reflect a gap between the rate of nominal wage growth and the rate of return on the stable value fund since wages are in the denominator of the balance-to-pay ratio. Likewise, 
an employee who was automatically enrolled during her first month of tenure in Company B would accumulate $3 \%$ of her paycheck in a money market fund each month. If we assume that the return on her money market fund was roughly equal to the rate of growth in her nominal earnings, this worker would have a balance to pay ratio of $(3 \%)(12 / 12+11 / 12)(1.5)=8.6 \%$ at the beginning of her $24^{\text {th }}$ month at Company B. This predicted accumulation level is comparable to the empirical accumulation level of $7.3 \%$ (at the $25^{\text {th }}$ percentile of the balance-to-pay distribution).

In the $50^{\text {th }}$ percentile of the distribution, we see non-zero balance accumulations for employees hired before and after automatic enrollment in both companies. Over the tenure ranges plotted in Figure 6, employees at the $50^{\text {th }}$ percentile of the balance-to-pay distribution hired after automatic enrollment have greater asset accumulation than do employees hired prior to automatic enrollment in Company B. This is also true in Company A for tenures of less than four years. This is due largely to the fact that before automatic enrollment, the typical employee does not join the 401(k) plan until he or she has worked for one to two years (see Figure 1).

At the $75^{\text {th }}$ and $90^{\text {th }}$ percentiles of the balance-to-pay ratio, the asset accumulation profiles look fairly similar for employees hired before and after automatic enrollment. For Company A, the profiles are nearly indistinguishable. For Company B, employees hired after automatic enrollment at all tenure levels have slightly lower levels of asset accumulation at both the $75^{\text {th }}$ and $90^{\text {th }}$ percentile, although the differences between the two groups are small.

In summary, Figures 5 and 6 tell a mixed story about the impact of automatic enrollment on asset accumulation. Automatic enrollment increases participation, raising wealth accumulation. But the typical automatic enrollment plan anchors participants at a low contribution rate and in a conservative asset class, lowering wealth accumulation. On average, these effects appear to be approximately offsetting. However, automatic enrollment does increase wealth accumulation in the lower tail of the wealth distribution by dramatically reducing the fraction of employees that do not participate in the 401(k) plan.

It is also useful to augment our study by analyzing a complementary measure of wealth accumulation: the average $401(\mathrm{k})$ contribution rate. This wealth accumulation measure is not distorted by the variability in market returns that potentially biases our analysis of balance-to-pay ratios. Recall that our data covers the latter half of the 1990s and that in all three companies automatic enrollment was implemented in 1997 or 1998. Thus, employees hired before the 
adoption of automatic enrollment had the benefit of a spectacular bull market, while those hired after automatic enrollment were more likely to experience a period of relatively flat equity performance. Such bull market effects will influence balance-to-pay ratios but may have only a small impact on average contribution rates.

Figures $7 \mathrm{~A}$ and $7 \mathrm{~B}$ plot the average contribution rates with respect to tenure of employees from Company A and Company B. Each figure plots an average contribution rate profile for employees hired before automatic enrollment and a profile for employees hired after automatic enrollment. The average contribution rate in these profiles includes all employees in the relevant tenure groups, including those who elect not to participate in the plan. We find that automatic enrollment weakly raises the average contribution rate. This effect is strongest for Company B, where the effect is a little less than one percentage point. ${ }^{20}$

This contribution rate analysis abstracts away from asset allocation issues. However, asset allocation decisions cannot be ignored and they will probably continue to have important effects in the future. One way to gauge the long-run impact of the conservative investment default is to ask whether the default still has an effect after participants make at least one active decision in their 401(k) plan. Table 5 addresses this question by comparing participants hired before automatic enrollment to all participants hired after after automatic enrollment, as well as the subset of participants hired after automatic enrollment who have elected at some point to change their 401(k) savings elections away from either the default contribution rate, the default investment fund, or both.

Participants hired before automatic enrollment (column 1 of Table 5) are much less likely than participants hired after automatic enrollment (column 2) to have any balances in the default fund and to have all their balances in the default fund. In addition, participants hired before automatic enrollment have a lower fraction of balances in the default fund. ${ }^{21}$ Of greater interest is the comparison of participants hired before automatic enrollment (column 1) to the subset of

\footnotetext{
${ }^{20}$ Note that the slope of the average contribution rate profile is driven mostly by increases in the 401(k) participation rate for employees hired prior to automatic enrollment, and mostly by movements away from the default contribution rate for employees hired after automatic enrollment.

${ }^{21}$ For Company A, the fraction of balances in the default fund is calculated excluding company matching contributions, which are made in company stock, from the denominator. We make this exclusion because participants cannot elect to reallocate these matching contributions out of company stock until reaching the age of 55. Thus, they do not represent balances over which the individuals have any control. Because participants can reallocate their matching contributions out of company stock upon reaching age 55, we also restrict the sample for Company A in Table 5 to individuals under the age of 55.
} 
the participants hired after automatic enrollment who have changed some aspect of their 401(k) savings away from at least one of the defaults (column 3). In all three companies, participants hired before automatic enrollment are less likely to have any balances in the default fund and have a lower fraction of balances in the default fund than do participants hired under automatic enrollment who have made at least one active savings election. In Companies B and C, participants hired before automatic enrollment are also less likely to be wholly invested in the default fund than are participants hired under automatic enrollment who have made some change to the parameters of their 401(k) participation. Hence, it appears that the conservative investment defaults act as an anchor, even for participants who actively make changes to their 401(k) plan.

We conclude our analysis by asking what happens to 401(k) balances when a job separation occurs. Several recent papers suggest that a substantial fraction of individuals who change jobs take their 401(k) balances from a previous employer as cash distributions, and that this is particularly likely to be true for employees with low account balances. ${ }^{22}$ Unfortunately, we do not have the data that would reveal whether automatic enrollment simply results in shortterm deferred consumption for terminated employees or whether these employees actually continue to hold higher levels of retirement savings even after termination. For Companies A and $\mathrm{C}$, however, we do have some information that is potentially informative. Our data for these two companies includes terminated employees who had some account activity during the previous calendar year, along with their date of termination, whether a final distribution of the 401(k) balances was made from the account, and whether this final distribution was rolled directly over into another qualified plan or taken as a cash distribution. Because we have administrative data, we do not know whether cash distributions were subsequently rolled into a qualified plan by the participant receiving the distribution. However, from previous research on 401(k) distributions, we know that the likelihood of a cash distribution being used for consumption is high for low account balances, ${ }^{23}$ and we can look to see whether employees hired

\footnotetext{
${ }^{22}$ See, for example, Poterba, Venti and Wise (1998) and McCarthy and McWhirter (2000).

${ }^{23}$ Poterba, Venti and Wise (1998) report that the probability that a cash distribution is rolled over into an IRA or another emp loyer's plan is only 5 to 16 percent for distributions of less than $\$ 5000$. The probability that a cash distribution is rolled over into an IRA or another employer's plan or invested in some other savings vehicle is slightly higher at 14 to 33 percent.
} 
under automatic enrollment are more likely to have a cash distribution than are employees hired prior to automatic enrollment.

To do this, we take the subset of all employees in Companies $\mathrm{A}$ and $\mathrm{C}$ who were active plan participants on December 31, 1998 or 1999 but whose employment terminated sometime in 1999 or 2000. These employees appear in the 1999 and 2000 data as terminated employees, and have either a positive account balance if they have not taken a distribution, or a zero account balance and some positive value for final distributions if they have taken a cash distribution or a rollover. The average fraction of terminated employees who received a cash distribution is $67 \%$ in Company A and 64\% in Company C. Using the entire group of terminated plan participants, we estimate a linear probability regression for the likelihood of having a cash distribution as a function of gender, age, pay, the month of termination, and whether the employee was hired under automatic enrollment. All of these variables, except the month of termination, are computed on December 31 of the year prior to termination.

The first and third columns of Table 6 show the coefficients from this regression for Company $\mathrm{A}$ and $\mathrm{C}$ respectively. We do not report the month of termination coefficients, which are all highly significant but economically uninteresting (the likelihood of a distribution increases with the length of time since the job ended). Younger employees are slightly more likely to take a distribution in Company A, as are lower paid individuals in both Companies A and C. Employees with greater levels of tenure, however, are less likely to take a cash distribution. Our key variable of interest, however, is whether an individual was hired under automatic enrollment. For Company $\mathrm{C}$ we are also able to analyze the effect of becoming subject to automatic enrollment as a non-participant who was hired before automatic enrollment. $^{24}$ In Company A, being subject to automatic enrollment as a new hire increases the probability of a distribution by 10 percentage points. In Company $\mathrm{C}$, in contrast, automatic enrollment appears to have little impact on taking a cash distribution for those hired under automatic enrollment. Individuals subject to automatic enrollment as non-participants in Company $\mathrm{C}$, however, are 18 percentage points more likely to take a distribution than are individuals not subject to automatic enrollment, although this effect is only significant at the $10 \%$ level.

\footnotetext{
${ }^{24}$ Note that this particular regression coefficient confounds both treatment and selection effects.
} 
The positive effect of automatic enrollment on taking a distribution in Company A (and on those who were hired before but first participated after automatic enrollment in Company C) could be driven by the "coerced" participation of individuals subject to automatic enrollment who, not really having wanted to save in the first place, use a job termination to access their 401(k) balances in order to consume them. Alternatively, these results could be driven by the fact that participants who were subject to automatic enrollment tend to have low 401(k) account balances. The induced participants under automatic enrollment have a low contribution rate, correspondingly lower employer matching contributions, and lower returns from the conservative default fund. In general, low-balance accounts tend to be distributed at a higher rate than high-balance accounts because employers may compel a cash distribution of low account balances $(<\$ 5,000)$ for terminated employees if the employee does not elect a roll-over into another qualified plan.

We can gauge the extent to which lower account balances are driving the positive automatic enrollment coefficients in columns 1 and 3 by including measures of balance size (see columns 2 and 4 of Table 6). When we do so, the magnitude of the automatic enrollment effect is virtually unchanged in Company A. In Company $\mathrm{C}$, in contrast, the automatic enrollment coefficients decline quite significantly in magnitude (and in fact, become negative) and are not statistically significant. Thus, the effect of automatic enrollment on the likelihood of taking a cash distribution appears to vary quite substantially across these two companies.

It is also interesting to analyze the balance coefficients themselves. All but one of the balance measures is large and significant for both companies. Employees with balances of less than $\$ 5,000$ are 34-69 (18-51) percentage points more likely to receive a cash distribution than are employees with balances in excess of $\$ 10,000$ in Company A (Company C). Employees with balances between $\$ 5,000$ and $\$ 10,000$, however, are no more likely to receive a cash distribution than are their counterparts with higher balances. In both companies, these coefficients imply that there is a rather significant drop in the probability of a cash distribution once balances reach a threshold of $\$ 5,000$. Interestingly, $\$ 5,000$ corresponds to the legal threshold below which employers can compel a cash distribution for terminated employees. ${ }^{25,26}$

\footnotetext{
${ }^{25}$ Given this threshold, one might expect that all employees with balances of less than $\$ 5,000$ would receive a cash distribution. There are two reasons why we do not observe this in our data. First, employees with balances of less than $\$ 5,000$ may elect a direct rollover to another qualified plan before the compelled distribution would occur. (continued on next page)
} 
These results suggest that the effectiveness of automatic enrollment at increasing overall retirement savings accumulation will depend on the fraction of employees whose tenure ends before they reach the $\$ 5,000$ balance threshold at which employers can compel cash distributions. Note that the law gives employers the option to compel a cash distribution for terminated employees with low account balances. Employers could choose to retain these balances unless the employee requests a distribution or a rollover. Alternatively, the employer could automatically roll over the account balances into an IRA unless the employee requests some other type of distribution. ${ }^{27}$ Our evidence on the importance of defaults suggests that either of these actions would increase the impact of automatic enrollment on long-term retirement savings.

Going forward, the problem of automatic cash distributions for terminated employees with low account balances will be substantially lessened as recently enacted provisions of the Economic Growth and Tax Relief Reconciliation Act of 2001 take effect. This law changes the default treatment of $\$ 1,000$ to $\$ 5,000$ account balances for terminated employees. Under the new law, employers will no longer be able to compel a cash distribution if a former employee does not elect a rollover; rather, employers will be required to establish an IRA on behalf of participants if they choose not the maintain these accounts. Although this provision of the law will not take effect until regulations are issued by the Department of Labor (which must be done by June 2004), it will make automatic enrollment a more effective retirement savings tool when finally implemented.

\footnotetext{
Second, our measure of balances is that on December 31 of the year prior to termination, and is thus an imperfect measure of actual balances at the date of termination (in particular, it is likely to understate balances at the date of termination). Some employees with year-end balances of less than $\$ 5,000$ will have balances in excess of $\$ 5,000$ upon termination and thus will not be subject to an automatic cash distribution. This is more likely to be true for employees with higher year-end balances, which is consistent with the pattern of balance coefficients reported in Table 6. See Choi et al. (2001) for a more detailed analysis of automatic cash distributions for individuals with balances below $\$ 5,000$ at these two companies.

${ }^{26}$ We should note that although employers can compel a cash distribution for terminated employees with an account balance of less than $\$ 5,000$, the employee can take this distribution and roll it over into an IRA or another employer's retirement savings plan with no negative tax consequences. As noted earlier, however, the previous literature on this subject suggests that most of these small distributions are in fact consumed.

${ }^{27}$ This type of automatic rollover was sanctioned in IRS Revenue Ruling 2000-36 (Internal Revenue Service 2000b).
} 


\section{Conclusions}

Automatic enrollment dramatically changes 401(k) savings behavior. Most employees passively accept the automatic enrollment defaults, including the default savings rate and the default fund. This default behavior has an ambiguous impact on total savings. High 401(k) participation rates increase wealth accumulation, but low default savings rates and conservative default investment funds undercut wealth accumulation. We have traced out these effects over a two to four year horizon in three different companies.

For the two companies in which we can evaluate asset accumulation, automatic enrollment probably had a modest positive impact on employee balances, controlling for tenure. For Company A, automatic enrollment raised the average balance-to-pay ratio. For Company B, automatic enrollment did not affect the average balance-to-pay ratio. However, our analysis implicitly disadvantages automatic enrollment, because employees hired before automatic enrollment enjoyed a period of abnormally high equity returns. Had equity returns in the mid1990s been typical instead of extraordinary, the employees hired before automatic enrollment would have had lower $401(\mathrm{k})$ balances, and hence would have achieved less wealth accumulation than the employees hired after automatic enrollment.

We also look at average contribution rates both before and after automatic enrollment. Averaging over all employees, including those with zero contribution rates, we find that automatic enrollment in our companies raises the average contribution rate by roughly half a percentage point.

Whether or not automatic enrollment had a positive impact on wealth accumulation, our analysis demonstrates that defaults make an enormous difference. For the companies in our study, automatic enrollment dramatically changes the distribution of wealth accumulation across employees. Automatic enrollment effectively cuts off the lower tail of the distribution (the employees who were not contributing), raising the participation rate to around $90 \%$.

For the firms in our sample, automatic enrolled failed to dramatically raise wealth accumulation because of the conservative nature of the automatic enrollment defaults. Default savings rates of two to three percent of income and default investments in money market accounts undermine long-term wealth accumulation. Firms seeking to increase employee savings should adopt automatic enrollment with more aggressive defaults, including defaults that slowly raise the employee's contribution rate over time (e.g. Benartzi and Thaler, 2001). Such 
firms may also want to consider either maintaining the small $(<5,000)$ account balances of terminated employees or automatically rolling them over into an IRA.

Of course, some firms may not wish to increase the aggressiveness of their defaults. High default savings rates may lead employees to "oversave," although there is a growing body of evidence that workers overwhelmingly perceive themselves as saving too little and welcome mechanisms that help them save more. ${ }^{28}$ High default savings rates may increase firm matching costs. ${ }^{29}$ Aggressive default investment funds, including equity exposure, may leave the firm vulnerable to employee lawsuits when volatile asset classes suffer capital losses. We do not know what a firm should optimally do. But we can confidently conclude that firms have the power to dramatically change patterns of retirement saving by simply changing the defaults that their employees face.

\footnotetext{
${ }^{28}$ See Choi et al. (2001) and Benartzi and Thaler (2001).

${ }^{29}$ In equilibrium these increased matching costs should be offset with reduced rates of wage growth. However, employees and their unions may not be willing to make wage concessions in light of higher effective match rates. Hence, some firms may see highly successful retirement plans as a source of higher labor costs.
} 


\section{References}

Benartzi, Shlomo and Richard Thaler (2001). "Save More Tomorrow: Using Behavioral Economics to Increase Employee Saving," University of California-Los Angeles Working Paper.

Choi, James J., David Laibson, Brigitte C. Madrian, and Andrew Metrick (forthcoming).

"Defined Contribution Pensions: Plan Rules, Participant Decisions, and the Path of Least Resistance," in James M. Poterba, ed., Tax Policy and the Economy, Vol. 16 (Cambridge, MA: MIT Press).

Internal Revenue Service (1998). Internal Revenue Bulletin 98-25 (June 22, 1998), p. 8. Downloaded from http://ftp.fedworld.gov/pub/irs-irbs/irb98-25.pdf.

Internal Revenue Service (2000a). Internal Revenue Bulletin 2000-7 (February 14, 2000), p. 617. Downloaded from http://ftp.fedworld.gov/pub/irs-irbs/irb00-7.pdf.

Internal Revenue Service (2000b). Internal Revenue Bulletin 2000-31 (July 31, 2000), pp. 138142. Downloaded from http://ftp.fedworld.gov/pub/irs-irbs/irb00-31.pdf.

Madrian, Brigitte C. and Dennis F. Shea (2001). "The Power of Suggestion: Inertia in 401(k) Participation and Savings Behavior," Quarterly Journal of Economics (forthcoming).

McCarthy, Mike and Liz McWhirter (2000). "Are Employees Missing the Big Picture? Study Shows Need for Ongoing Financial Education," Benefits Quarterly 16: 25-31.

Poterba, James M. Steven F. Venti and David A. Wise (1998). "Lump Sum Distributions from Retirement Savings Plans: Receipt and Utilization," in David A. Wise, ed., Inquiries in the Economics of Aging (Chicago: University of Chicago Press) 85-105.

Profit Sharing/401(k) Council of America (2001). "Automatic Enrollment 2001: A Study of Automatic Enrollment Practices in 401(k) Plans." Downloaded from http://www.pcsa.org/data/autoenroll2001.asp on April 19, 2001.

Vanguard Center for Retirement Research (2001). "Automatic Enrollment: Vanguard Client Experience." Downloaded from http://institutional.vanguard.com/pdf/automatic_enrollment_clientexp.pdf on September 6, 2001. 


\section{TABLE 1. Automatic Enrollment in Three Companies}

\begin{tabular}{|c|c|c|c|}
\hline & Company A & Company B & Company $\mathrm{C}$ \\
\hline Industry & Office Equipment & Health Services & Food Products \\
\hline Employment & 32,000 & 30,000 & 18,000 \\
\hline $\begin{array}{l}\text { Date automatic enrollment } \\
\text { implemented }\end{array}$ & January 1, 1997 & April 1, 1998 & $\begin{array}{ll}\text { A) } & \text { January } 1,1998^{\mathrm{a}} \\
\text { B) } & \text { November } 1,1999^{\mathrm{a}}\end{array}$ \\
\hline $\begin{array}{l}\text { Employees affected by } \\
\text { automatic enrollment }\end{array}$ & $\begin{array}{l}\text { Hired on or after } \\
\text { January } 1,1997\end{array}$ & $\begin{array}{l}\text { Hired on or after } \\
\text { April } 1,1998\end{array}$ & $\begin{array}{l}\text { A) Eligible on or after } \\
\text { January } 1,1998^{\mathrm{a}} \\
\text { B) Eligible before January 1, } \\
1998 \text { and not participating } \\
\text { on November } 1,1999^{\mathrm{a}}\end{array}$ \\
\hline Length of opt-out period & 60 days & 30 days & 30 days \\
\hline Default contribution rate & $2 \%$ & $3 \%$ & $3 \%$ \\
\hline Default investment fund & Stable value & Money market & Stable value \\
\hline Matching provisions & $\begin{array}{l}\$ 0.67 / \$ 1 \text { up to } 6 \% \text { of pay put } \\
\text { into company stock }\end{array}$ & $\begin{array}{l}\$ 0.50 / \$ 1 \text { up to } 6 \% \text { of pay after } \\
1 \text { year of employment }\end{array}$ & $\$ 0.50 / \$ 1$ up to $6 \%$ of pay \\
\hline $\begin{array}{l}\text { Other changes in } 401(\mathrm{k}) \text { plan } \\
\text { over study period }\end{array}$ & $\begin{array}{l}\text { Three new funds in } 1999 \\
\text { One fund closed in } 1999\end{array}$ & $\begin{array}{l}1 \text { year length of service } \\
\text { requirement eliminated on } \\
\text { April } 1,1998\end{array}$ & $\begin{array}{l}1 \text { year length of service } \\
\text { requirement for employees } \\
\text { under age } 40 \text { eliminated on } \\
\text { January } 1,1998\end{array}$ \\
\hline \multicolumn{4}{|c|}{$\begin{array}{l}\text { Source: Summary plan descriptions and conversations with company officials. } \\
\text { a In Company C, the first round of automatic enrollment affected employees eligible on or after January } 1,1998 \text {. This includes all employees hired on or after } \\
\text { January } 1,1998 \text { as well as any employees hired during } 1997 \text { who were under the age of } 40 \text { on December } 31,1997 \text {. The second round of automatic enrollment } \\
\text { in Company C affected all employees not subject to automatic enrollment during the first round: those hired prior to } 1997 \text { and employees hired during } 1997 \\
\text { who had reached the age of } 40 \text { by December } 31,1997 \text {. }\end{array}$} \\
\hline
\end{tabular}


TABLE 2. The Distribution of 401(k) Contribution Rates by Tenure for Employees

Hired Before and After Automatic Enrollment

\begin{tabular}{|c|c|c|c|c|c|c|c|c|}
\hline \multirow[b]{2}{*}{$\begin{array}{l}\text { Tenure } \\
\text { (months) }\end{array}$} & \multicolumn{4}{|c|}{ Hired Before Automatic Enrollment } & \multicolumn{4}{|c|}{ Hired After Automatic Enrollment } \\
\hline & $\begin{array}{c}\text { Non- } \\
\text { Participant }\end{array}$ & $<$ Default & Default & $>$ Default & $\begin{array}{c}\text { Non- } \\
\text { Participant } \\
\end{array}$ & $<$ Default & Default & $>$ Default \\
\hline \multicolumn{9}{|c|}{ Company A } \\
\hline 6-11 & -- & -- & -- & -- & $8.4 \%$ & $1.3 \%$ & $63.4 \%$ & $26.9 \%$ \\
\hline $12-17$ & -- & -- & -- & -- & 8.5 & 1.4 & 61.0 & 29.1 \\
\hline $18-23$ & -- & -- & -- & -- & 8.8 & 1.4 & 56.5 & 33.4 \\
\hline $24-29$ & $46.9 \%$ & $1.7 \%$ & $12.0 \%$ & $39.4 \%$ & 9.0 & 1.7 & 53.3 & 36.1 \\
\hline $30-35$ & 40.8 & 1.4 & 10.9 & 46.9 & 8.4 & 1.6 & 50.3 & 39.7 \\
\hline $36-41$ & 40.2 & 1.7 & 12.7 & 45.5 & 6.8 & 1.3 & 48.5 & 43.4 \\
\hline $42-47$ & 35.3 & 0.9 & 10.7 & 53.2 & 8.3 & 1.6 & 45.8 & 44.3 \\
\hline $48-53$ & 31.5 & 1.9 & 13.4 & 53.3 & -- & -- & -- & -- \\
\hline \multicolumn{9}{|c|}{ Company B } \\
\hline $3-5$ & $68.9 \%$ & $3.0 \%$ & $3.6 \%$ & $24.5 \%$ & $13.5 \%$ & $1.2 \%$ & $71.8 \%$ & $13.6 \%$ \\
\hline $6-11$ & 64.0 & 3.0 & 4.4 & 28.6 & 13.7 & 1.3 & 66.2 & 18.9 \\
\hline $12-17$ & 64.2 & 2.7 & 3.4 & 29.8 & 12.7 & 1.6 & 54.9 & 30.8 \\
\hline $18-23$ & 53.4 & 3.4 & 4.5 & 38.8 & 12.0 & 1.5 & 47.5 & 39.0 \\
\hline $24-26$ & 47.3 & 3.9 & 5.3 & 43.6 & 12.1 & 1.4 & 41.4 & 45.0 \\
\hline
\end{tabular}


TABLE 3. The Distribution of 401(k) Fund Allocations by Tenure for Employees

Hired Before and After Automatic Enrollment

\begin{tabular}{|c|c|c|c|c|c|c|c|c|}
\hline \multirow[b]{2}{*}{$\begin{array}{l}\text { Tenure } \\
\text { (months) }\end{array}$} & \multicolumn{4}{|c|}{ Hired Before Automatic Enrollment } & \multicolumn{4}{|c|}{ Hired After Automatic Enrollment } \\
\hline & $\begin{array}{c}\text { Non- } \\
\text { Participant }\end{array}$ & $\begin{array}{c}\text { Zero } \\
\text { Balances }\end{array}$ & $\begin{array}{l}100 \% \text { Default } \\
\text { Fund }\end{array}$ & $\begin{array}{c}\text { Other } \\
\text { Allocation }\end{array}$ & $\begin{array}{c}\text { Non- } \\
\text { Participant }\end{array}$ & $\begin{array}{c}\text { Zero } \\
\text { Balances }\end{array}$ & $\begin{array}{l}100 \% \text { Default } \\
\text { Fund }\end{array}$ & $\begin{array}{c}\text { Other } \\
\text { Allocation }\end{array}$ \\
\hline \multicolumn{9}{|c|}{ Company A } \\
\hline 6-11 & -- & -- & -- & -- & $8.4 \%$ & $4.6 \%$ & $58.7 \%$ & $28.4 \%$ \\
\hline $12-17$ & -- & -- & -- & -- & 8.5 & 4.4 & 57.2 & 30.0 \\
\hline $18-23$ & -- & -- & -- & -- & 8.8 & 2.3 & 54.7 & 34.3 \\
\hline $24-29$ & $46.9 \%$ & $2.3 \%$ & $8.9 \%$ & $42.0 \%$ & 9.0 & 2.1 & 52.7 & 36.3 \\
\hline $30-35$ & 40.8 & 1.9 & 6.2 & 51.1 & 8.4 & 1.4 & 49.8 & 40.4 \\
\hline $36-41$ & 40.2 & 1.5 & 8.8 & 49.4 & 6.8 & 1.3 & 49.1 & 42.8 \\
\hline $42-47$ & 35.3 & 0.8 & 6.7 & 57.2 & 8.3 & 1.2 & 47.2 & 43.2 \\
\hline $48-53$ & 31.5 & 0.9 & 8.8 & 58.8 & -- & -- & -- & -- \\
\hline \multicolumn{9}{|c|}{ Company B } \\
\hline $3-5$ & $68.9 \%$ & -- & $0.7 \%$ & $30.4 \%$ & $13.6 \%$ & -- & $76.7 \%$ & $9.7 \%$ \\
\hline $6-11$ & 64.0 & -- & 0.9 & 35.1 & 13.5 & -- & 71.2 & 15.3 \\
\hline $12-17$ & 64.2 & -- & 2.9 & 32.9 & 13.7 & -- & 64.0 & 22.3 \\
\hline $18-23$ & 53.4 & -- & 2.2 & 44.4 & 12.0 & -- & 50.0 & 38.0 \\
\hline $24-26$ & 47.3 & -- & 2.3 & 50.4 & 12.1 & -- & 43.6 & 44.3 \\
\hline
\end{tabular}


TABLE 4A. Default Savings Behavior of 401(k) Participants Under Automatic Enrollment

$$
\text { Company A }
$$

Company B

(Hired After Automatic Enrollment)

(Hired After Automatic Enrollment)

\begin{tabular}{|c|c|c|c|c|c|c|}
\hline & Default rate \& fund & Default rate & Default fund & Default rate $\&$ fund & Default rate & Default fund \\
\hline \multirow[t]{2}{*}{ Constant } & $0.4654 * *$ & $0.5221^{* *}$ & $0.4828^{* *}$ & $0.6691 * *$ & $0.7439 * *$ & $0.7304 * *$ \\
\hline & $(0.0148)$ & $(0.0144)$ & $(0.0147)$ & $(0.0136)$ & $(0.0132)$ & $(0.0125)$ \\
\hline \multirow[t]{2}{*}{ Tenure } & $-0.0061 * *$ & $-0.0069 * *$ & $-0.0047 * *$ & $-0.0265 * *$ & $-0.0256^{* *}$ & $-0.0226 * *$ \\
\hline & $(0.0008)$ & $(0.0008)$ & $(0.0008)$ & $(0.0014)$ & $(0.0015)$ & $(0.0015)$ \\
\hline \multirow[t]{2}{*}{ Female } & 0.0178 & $0.0241 * *$ & $0.0182 *$ & $0.0388 * *$ & 0.0180 & $0.0446 * *$ \\
\hline & $(0.0093)$ & $(0.0088)$ & $(0.0091)$ & $(0.0101)$ & $(0.0097)$ & $(0.0093)$ \\
\hline \multirow[t]{2}{*}{ Low pay } & $0.3263 * *$ & $0.2999 * *$ & $0.3172 * *$ & $0.2366 * *$ & $0.1977 * *$ & $0.1853 * *$ \\
\hline & $(0.0113)$ & $(0.0108)$ & $(0.0111)$ & $(0.0098)$ & $(0.0094)$ & $(0.0088)$ \\
\hline \multirow[t]{2}{*}{ Middle pay } & $0.1660 * *$ & $0.1609 * *$ & $0.1707 * *$ & $0.1975 * *$ & $0.1739 * *$ & $0.1632 * *$ \\
\hline & $(0.0117)$ & $(0.0113)$ & $(0.0117)$ & $(0.0100)$ & $(0.0095)$ & $(0.0090)$ \\
\hline \multirow[t]{2}{*}{ Age $<30$} & $0.1260 * *$ & $0.1102 * *$ & $0.1196 * *$ & $0.0390 * *$ & $0.0406 * *$ & $0.0312 * *$ \\
\hline & $(0.0150)$ & $(0.0142)$ & $(0.0146)$ & $(0.0120)$ & $(0.0114)$ & $(0.0108)$ \\
\hline \multirow[t]{2}{*}{ Age 30-44 } & $0.0577 * *$ & $0.0519 * *$ & $0.0600 * *$ & 0.0087 & 0.0100 & 0.0100 \\
\hline & $(0.0152)$ & $(0.0146)$ & $(0.0150)$ & $(0.0120)$ & $(0.0114)$ & $(0.0108)$ \\
\hline \multirow[t]{2}{*}{ Tenure*Female } & -0.0006 & -0.0007 & 0.0001 & $0.0033 * *$ & $0.0041 * *$ & $0.0029 *$ \\
\hline & $(0.0005)$ & $(0.0005)$ & $(0.0005)$ & $(0.0011)$ & $(0.0012)$ & $(0.0011)$ \\
\hline \multirow[t]{2}{*}{ Tenure*Low pay } & $0.0019 * *$ & $0.0027 * *$ & $0.0024 * *$ & $0.0076^{* *}$ & $0.0078 * *$ & $0.0105^{* *}$ \\
\hline & $(0.0006)$ & $(0.0006)$ & $(0.0006)$ & $(0.0012)$ & $(0.0012)$ & $(0.0012)$ \\
\hline \multirow[t]{2}{*}{ Tenure*Middle pay } & $0.0019 * *$ & $0.0023 * *$ & $0.0022 * *$ & $0.0033 * *$ & $0.0042 * *$ & $0.0057 * *$ \\
\hline & $(0.0006)$ & $(0.0006)$ & $(0.0006)$ & $(0.0012)$ & $(0.0012)$ & $(0.0012)$ \\
\hline \multirow[t]{2}{*}{ Tenure*Age $<30$} & $-0.0019^{*}$ & -0.0010 & $-0.0023^{* *}$ & 0.0004 & 0.0020 & -0.0015 \\
\hline & $(0.0018)$ & $(0.0008)$ & $(0.0008)$ & $(0.0014)$ & $(0.0014)$ & $(0.0014)$ \\
\hline \multirow[t]{2}{*}{ Tenure*Age 30-44 } & -0.0013 & -0.0003 & $-0.0019 *$ & $0.0027 *$ & $0.0035 * *$ & 0.0000 \\
\hline & $(0.0008)$ & $(0.0008)$ & $(0.0008)$ & $(0.0013)$ & $(0.0014)$ & $(0.0014)$ \\
\hline Sample size & 37,365 & 38,992 & 37,365 & 51,157 & 51,157 & 51,157 \\
\hline $\mathrm{R}^{2}$ & 0.1249 & 0.1215 & 0.1211 & 0.1728 & 0.1561 & 0.1569 \\
\hline
\end{tabular}


TABLE 4B. Default Savings Behavior of 401(k) Participants Under Automatic Enrollment

Company C Company C (Hired Before

(Hired After Automatic Enrollment) But First Participated After Automatic Enrollment)

\begin{tabular}{|c|c|c|c|c|c|c|}
\hline & & \\
\hline & Default rate $\&$ fund & Default rate & Default fund & Default rate $\&$ fund & Default rate & Default fund \\
\hline \multirow[t]{2}{*}{ Constant } & $0.2836^{* *}$ & $0.3424 * *$ & $0.3039^{* *}$ & $0.9761^{* *}$ & $0.9905^{* *}$ & $0.9852^{* *}$ \\
\hline & $(0.0373)$ & $(0.0382)$ & $(0.0375)$ & $(0.0163)$ & $(0.0119)$ & $(0.0131)$ \\
\hline \multirow[t]{2}{*}{ Tenure } & $-0.0089 * *$ & $-0.0097 * *$ & $-0.0051^{*}$ & -0.0015 & -0.0031 & -0.0011 \\
\hline & $(0.0019)$ & $(0.0020)$ & $(0.0022)$ & $(0.0048)$ & $(0.0047)$ & $(0.0049)$ \\
\hline \multirow[t]{2}{*}{ Female } & -0.0560 & $-0.0638^{*}$ & -0.0128 & 0.0771 & 0.0343 & 0.0560 \\
\hline & $(0.0324)$ & $(0.0322)$ & $(0.0299)$ & $(0.0505)$ & $(0.0417)$ & $(0.0399)$ \\
\hline \multirow[t]{2}{*}{ Low pay } & $0.5421 * *$ & $0.5032 * *$ & $0.5487 * *$ & $-0.1132 *$ & $-0.0628 *$ & -0.0730 \\
\hline & $(0.0378)$ & $(0.0384)$ & $(0.0397)$ & $(0.0462)$ & $(0.0314)$ & $(0.0384)$ \\
\hline \multirow[t]{2}{*}{ Middle pay } & $0.2176^{* *}$ & $0.2158 * *$ & $0.2032 * *$ & -0.0668 & -0.0612 & -0.0357 \\
\hline & $(0.0502)$ & $(0.0509)$ & $(0.0512)$ & $(0.0547)$ & $(0.0537)$ & $(0.0399)$ \\
\hline Age $<30$ & -- & -- & - & -- & -- & -- \\
\hline \multirow[t]{2}{*}{ Age $30-44$} & 0.0602 & $0.0665^{*}$ & $0.0647 *$ & $0.0894 *$ & $0.0550^{*}$ & $0.0581 *$ \\
\hline & $(0.0327)$ & $(0.0325)$ & $(0.0306)$ & $(0.0348)$ & $(0.0265)$ & $(0.0276)$ \\
\hline \multirow[t]{2}{*}{ Tenure*Female } & $0.0071 * *$ & $0.0073 * *$ & 0.0028 & $-0.0136 *$ & -0.0106 & $-0.0145^{*}$ \\
\hline & $(0.0020)$ & $(0.0020)$ & $(0.0019)$ & $(0.0064)$ & $(0.0056)$ & $(0.0060)$ \\
\hline \multirow[t]{2}{*}{ Tenure*Low pay } & -0.0005 & -0.0000 & 0.0009 & 0.0075 & 0.0033 & 0.0086 \\
\hline & $(0.0023)$ & $(0.0023)$ & $(0.0023)$ & $(0.0072)$ & $(0.0065)$ & $(0.0070)$ \\
\hline \multirow[t]{2}{*}{ Tenure*Middle pay } & -0.0037 & -0.0038 & 0.0010 & -0.0128 & -0.0080 & -0.0067 \\
\hline & $(0.0027)$ & $(0.0028)$ & $(0.0030)$ & $(0.0091)$ & $(0.0085)$ & $(0.0084)$ \\
\hline Tenure*Age $<30$ & -- & -- & -- & -- & -- & -- \\
\hline \multirow[t]{2}{*}{ Tenure*Age 30-44 } & 0.0008 & 0.0014 & -0.0006 & -0.0084 & -0.0017 & -0.0107 \\
\hline & $(0.0021)$ & $(0.0021)$ & $(0.0021)$ & $(0.0075)$ & $(0.0071)$ & $(0.0077)$ \\
\hline Sample size & 2,034 & 2,049 & 2,034 & 210 & 210 & 210 \\
\hline $\mathrm{R}^{2}$ & 0.2528 & 0.2290 & 0.2558 & 0.1101 & 0.0881 & 0.1034 \\
\hline
\end{tabular}

Coefficients estimated from a linear probability regression of the dependent variable (column head) on the independent variables listed. The sample in the first three columns includes all 401(k) participants aged $40+$ at the time of hire who were hired after automatic enrollment. The sample in the last three columns includes $401(\mathrm{k})$ participants aged $40+$ at the time of hire who were hired before automatic enrollment but who were not $401(\mathrm{k})$ participants when automatic enrollment became effective for employees of their hire cohort. Robust standard errors in parentheses. * denotes significance at the $5 \%$ level. $* *$ denotes significance at the $1 \%$ level. 


\section{TABLE 5. Retention of the Default Fund Among Non-Default Participants}

Subject to Automatic Enrollment

\begin{tabular}{|c|c|c|c|}
\hline & \multirow{2}{*}{$\begin{array}{c}\text { Hired Before } \\
\text { Automatic Enrollment }\end{array}$} & \multicolumn{2}{|c|}{ Hired After Automatic Enrollment } \\
\hline & & All & Made Change \\
\hline \multicolumn{4}{|l|}{ Company A (Tenure 24-35 months) } \\
\hline Any balances in the default fund & $35.5 \%$ & $71.7 \%$ & $41.5 \%$ \\
\hline All balances in the default fund & 13.8 & 58.1 & 12.6 \\
\hline Fraction of balances in the default fund & 19.1 & 62.5 & 21.9 \\
\hline \multicolumn{4}{|l|}{ Company B (Tenure 0-23 months) } \\
\hline Any balances in the default fund & $14.8 \%$ & $86.0 \%$ & $60.6 \%$ \\
\hline All balances in the default fund & 18.2 & 71.1 & 18.4 \\
\hline Fraction of balances in the default fund & 6.8 & 76.0 & 32.4 \\
\hline \multicolumn{4}{|l|}{ Company C (Tenure 12-35 months) } \\
\hline Any balances in the default fund & $27.5 \%$ & $59.8 \%$ & $33.9 \%$ \\
\hline All balances in the default fund & 13.0 & 54.3 & 20.1 \\
\hline Fraction of balances in the default fund & 16.9 & 55.7 & 23.8 \\
\hline \multicolumn{4}{|c|}{$\begin{array}{l}\text { Authors' calculations. The statistics in column } 1 \text { come from 12/1998 for Companies A and C and 12/1997 for Company B. The statistics in } \\
\text { columns } 2 \text { and } 3 \text { come from 12/1999 for Company A, 03/2000 for Company B, and 12/2000 for Company C. The fraction of balances in the } \\
\text { default fund in Company A excludes matching contributions made in company stock. The sample for Company A is } 401(\mathrm{k}) \text { participants } \\
\text { under the age of } 55 \text {. The sample for Company B is all 401(k) participants. The sample for Company C is } 401(\mathrm{k}) \text { participants aged } 40+\text { at the } \\
\text { time of hire. For Company C, the data in column } 1 \text { comes from before non-participants in the observed hire cohort became subject to } \\
\text { automatic enrollment. }\end{array}$} \\
\hline
\end{tabular}




\begin{tabular}{|c|c|c|c|c|}
\hline \multicolumn{5}{|c|}{ Table 6. Automatic Enrollment and the Dist } \\
\hline+2 & \multicolumn{2}{|c|}{ Company A } & \multicolumn{2}{|c|}{ Company C } \\
\hline 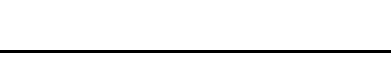 & Exclude balances & Include balances & Exclude balances & Include balances \\
\hline Constant & $\begin{array}{c}-0.1773 * * \\
(0.0315)\end{array}$ & $\begin{array}{c}-0.7513 * * \\
(0.0365)\end{array}$ & $\begin{array}{l}-0.1296 \\
(0.0175)\end{array}$ & $\begin{array}{l}-0.4068^{*} \\
(0.1832)\end{array}$ \\
\hline \multicolumn{5}{|l|}{ Automatic enrollment } \\
\hline Hired after AE & $\begin{array}{c}0.0960 * * \\
(0.0162)\end{array}$ & $\begin{array}{c}0.1001^{* *} \\
(0.0158)\end{array}$ & $\begin{array}{c}0.0528 \\
(0.0794)\end{array}$ & $\begin{array}{l}-0.1514 \\
(0.1194)\end{array}$ \\
\hline $\begin{array}{l}\text { Hired before } \mathrm{AE} \text { but first } \\
\text { participated after } \mathrm{AE}\end{array}$ & -- & -- & $\begin{array}{c}0.1802 \\
(0.0991)\end{array}$ & $\begin{array}{l}-0.0241 \\
(0.0781)\end{array}$ \\
\hline \multicolumn{5}{|l|}{ Balances } \\
\hline$\$ 0$ & -- & $\begin{array}{r}0.6647 * * \\
(0.0244)\end{array}$ & -- & -- \\
\hline$\$ 1-\$ 100$ & -- & $\begin{array}{c}0.6920 * * \\
(0.0247)\end{array}$ & -- & $\begin{array}{c}0.5119 * * \\
(0.1159)\end{array}$ \\
\hline$\$ 101-\$ 500$ & -- & $\begin{array}{c}0.6730 * * \\
(0.0216)\end{array}$ & -- & $\begin{array}{c}0.4899 * * \\
(0.1004)\end{array}$ \\
\hline$\$ 501-\$ 1000$ & -- & $\begin{array}{c}0.6205^{* *} \\
(0.0206)\end{array}$ & -- & $\begin{array}{r}0.3878 * * \\
(0.1021)\end{array}$ \\
\hline$\$ 1001-\$ 2000$ & -- & $\begin{array}{c}0.5353^{* *} \\
(0.0202)\end{array}$ & -- & $\begin{array}{c}0.3965 * * \\
(0.0925)\end{array}$ \\
\hline$\$ 2001-\$ 5000$ & -- & $\begin{array}{c}0.3387 * * \\
(0.0200)\end{array}$ & -- & $\begin{array}{l}0.1830^{*} \\
(0.0833)\end{array}$ \\
\hline$\$ 5001-\$ 10,000$ & -- & $\begin{array}{c}0.0457 \\
(0.0230)\end{array}$ & -- & $\begin{array}{c}0.0965 \\
(0.0865)\end{array}$ \\
\hline$>\$ 10,000$ (omitted) & -- & -- & -- & -- \\
\hline Female & $\begin{array}{l}-0.0042 \\
(0.0075)\end{array}$ & $\begin{array}{l}-0.0122 \\
(0.0070)\end{array}$ & $\begin{array}{l}-0.0738 \\
(0.0435)\end{array}$ & $\begin{array}{l}-0.1050^{*} \\
(0.0428)\end{array}$ \\
\hline \multicolumn{5}{|l|}{ Compensation } \\
\hline Low pay & $\begin{array}{r}0.2069 * * \\
(0.0100)\end{array}$ & $\begin{array}{c}0.0177 \\
(0.0111)\end{array}$ & $\begin{array}{l}0.4200 * * \\
(0.0567)\end{array}$ & $\begin{array}{c}0.2488 * * \\
(0.0634)\end{array}$ \\
\hline Middle pay & $\begin{array}{c}0.1681 * * \\
(0.0092)\end{array}$ & $\begin{array}{c}0.0050 \\
(0.0100)\end{array}$ & $\begin{array}{c}0.3086^{* *} \\
(0.0627)\end{array}$ & $\begin{array}{c}0.1901 * * \\
(0.0650)\end{array}$ \\
\hline High pay (omitted) & -- & -- & -- & -- \\
\hline \multicolumn{5}{|l|}{ Age } \\
\hline$<30$ & $\begin{array}{c}0.0649 * * \\
(0.0124)\end{array}$ & $\begin{array}{l}0.0281^{*} \\
(0.0117)\end{array}$ & -- & -- \\
\hline $30-44$ & $\begin{array}{c}0.0522 * * \\
(0.0126)\end{array}$ & $\begin{array}{c}0.0374 * * \\
(0.0118)\end{array}$ & $\begin{array}{c}0.0246 \\
(0.0465)\end{array}$ & $\begin{array}{c}0.0178 \\
(0.0451)\end{array}$ \\
\hline $45+($ omitted $)$ & -- & -- & & \\
\hline Tenure & $\begin{array}{c}-0.0024 * * \\
(0.0004)\end{array}$ & $\begin{array}{c}0.0056^{* *} \\
(0.0005)\end{array}$ & $\begin{array}{l}-0.0057^{*} \\
(0.0027)\end{array}$ & $\begin{array}{l}-0.0010 \\
(0.0027)\end{array}$ \\
\hline $\begin{array}{l}\text { Sample Size } \\
\mathrm{R}^{2}\end{array}$ & $\begin{array}{l}11,590 \\
0.3013\end{array}$ & $\begin{array}{l}11,590 \\
0.3910\end{array}$ & $\begin{array}{c}429 \\
0.3121\end{array}$ & $\begin{array}{c}429 \\
0.3681\end{array}$ \\
\hline $\begin{array}{l}\text { Coefficients estimated from } \\
\text { the independent variables li } \\
\text { active } 401(\mathrm{k}) \text { participants ur } \\
\text { sample in Company C is fur } \\
\text { parentheses. } * \text { denotes sign }\end{array}$ & $\begin{array}{l}\text { ir probability regres } \\
\text { d dummy variables } \\
\text { e } 65 \text { in } 1998 \text { and } 19 \\
\text { tricted to employee } \\
\text { ce at the } 5 \% \text { level. }\end{array}$ & $\begin{array}{l}\text { on of having taken } \\
\text { or the month/year of } \\
\text { whose employment } \\
\text { aged } 40+\text { at the tim } \\
\text { denotes significan }\end{array}$ & $\begin{array}{l}\text { on-rollover } 401(\mathrm{k}) \\
\text { ermination. The sa } \\
\text { rminated in } 1999 \text { at } \\
\text { f hire. Standard er } \\
\text { at the } 1 \% \text { level. }\end{array}$ & $\begin{array}{l}\text { istribution on } \\
\text { ple includes } \\
\text { I 2000. The } \\
\text { rs in }\end{array}$ \\
\hline
\end{tabular}



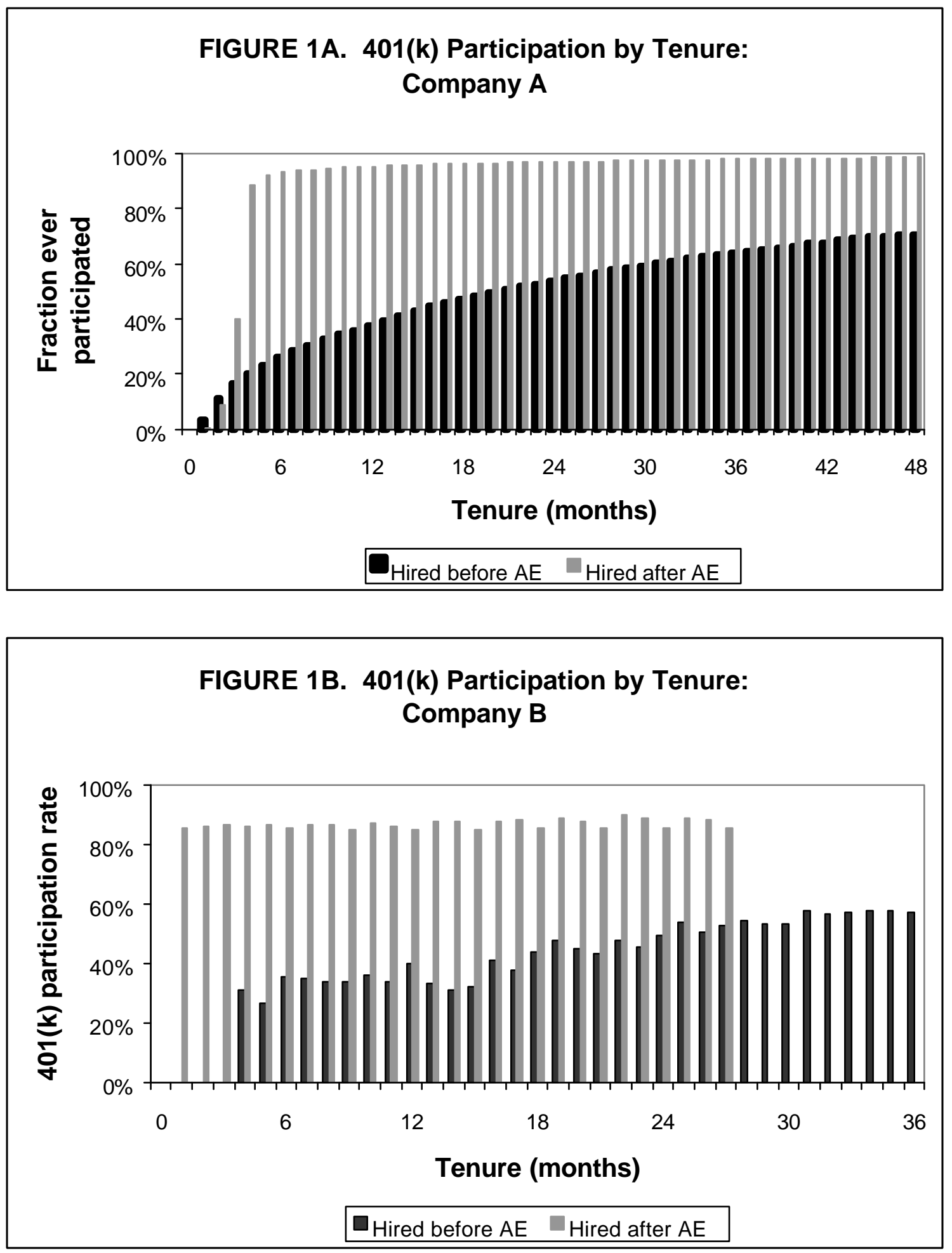

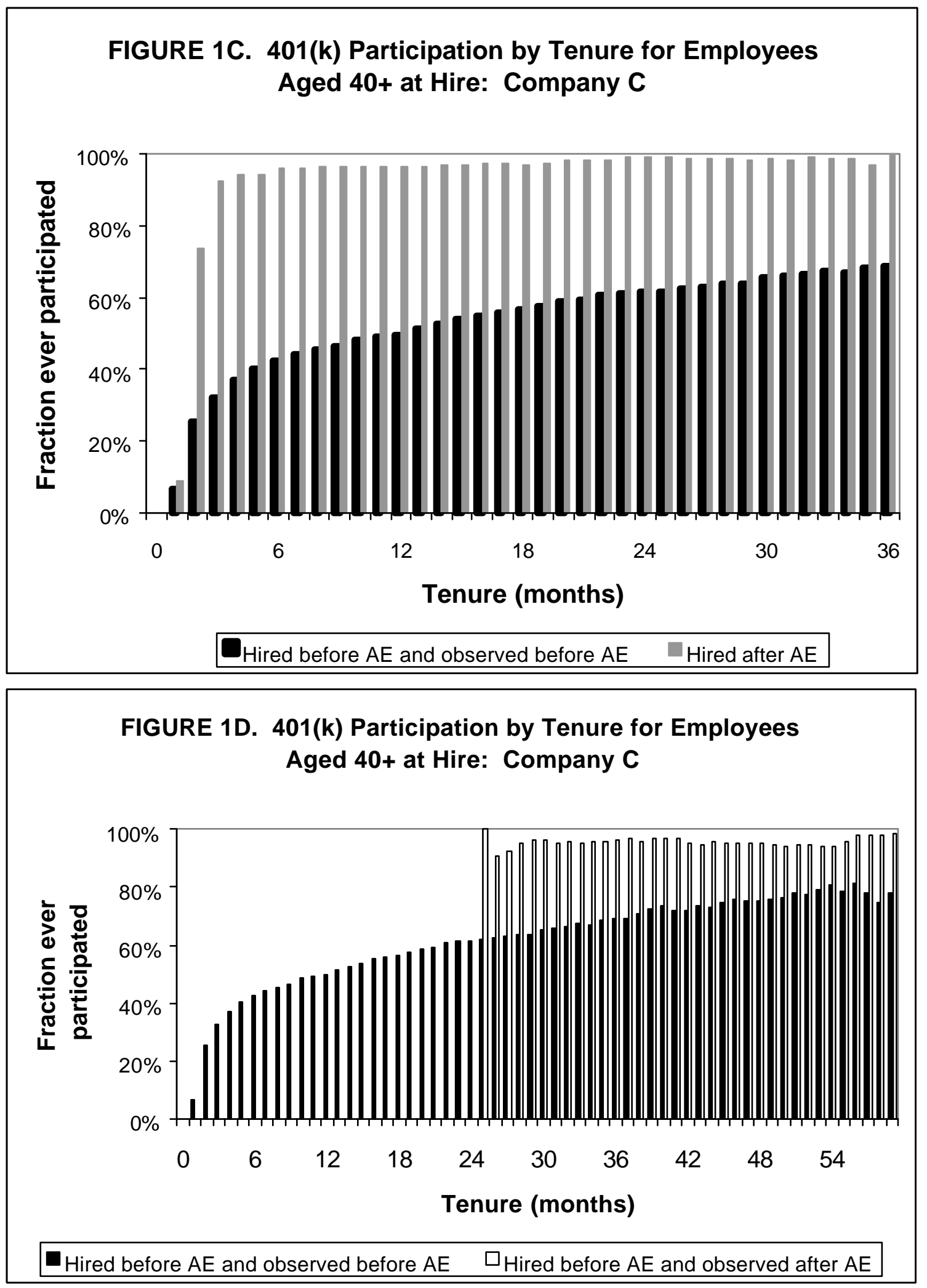

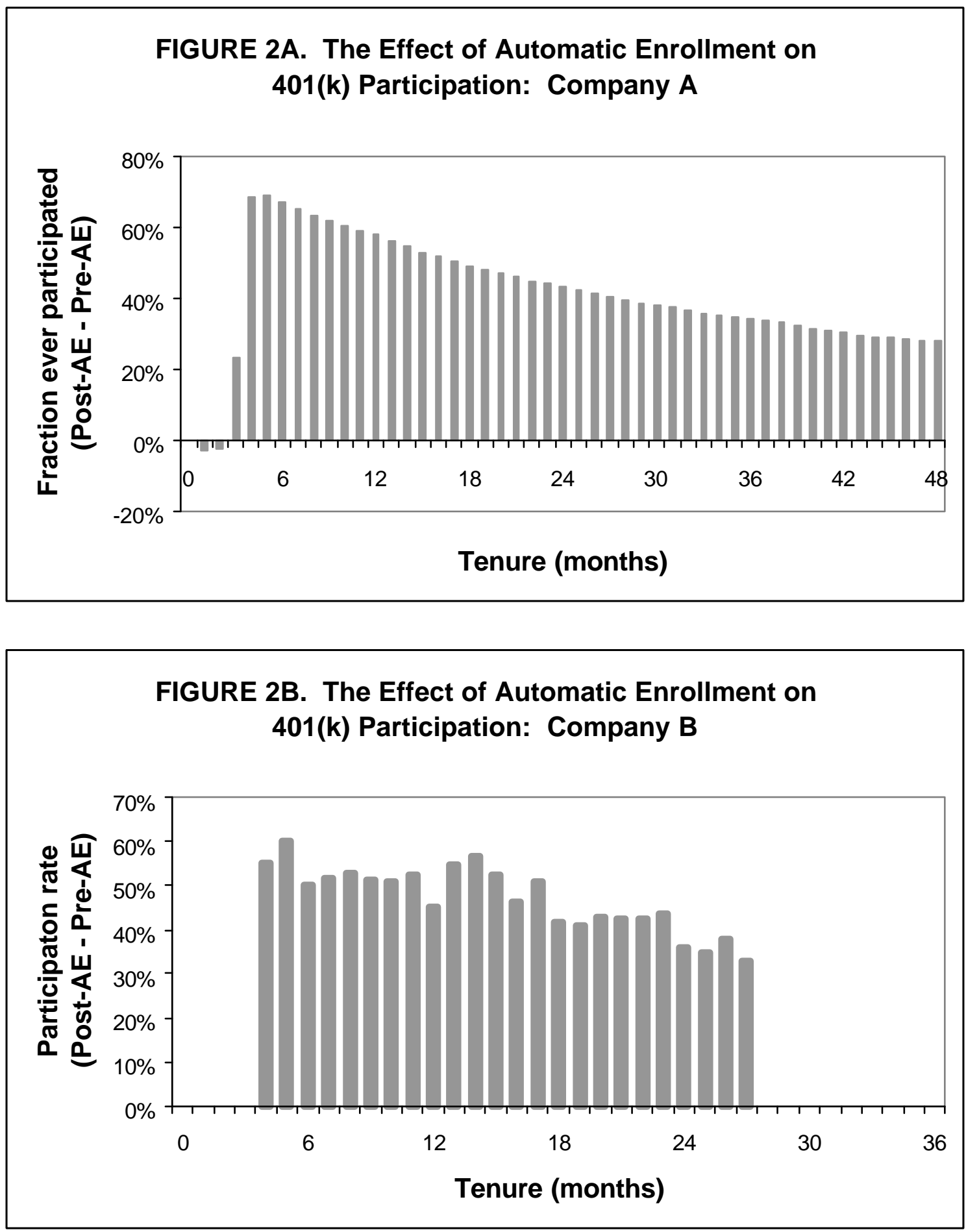


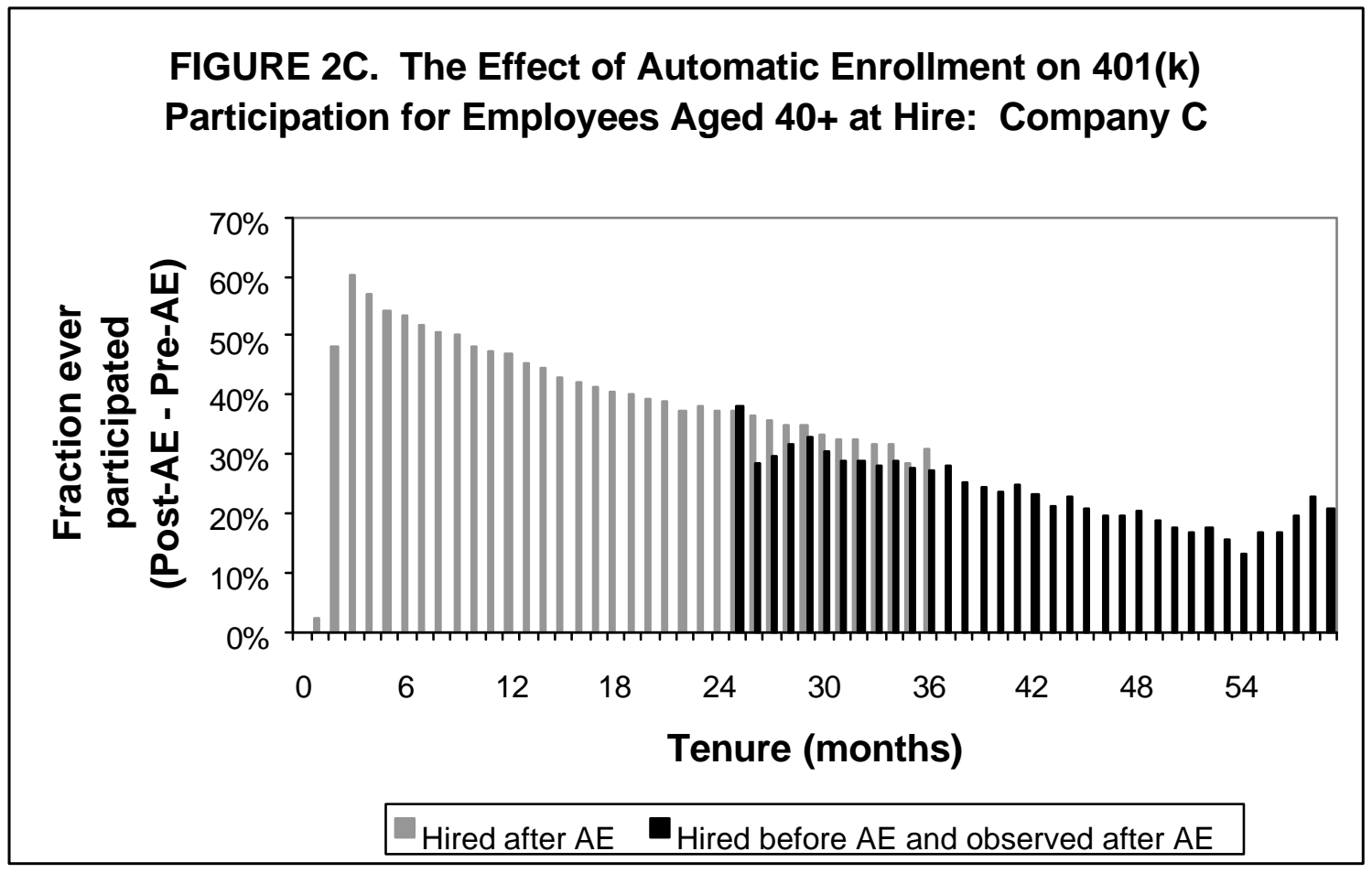



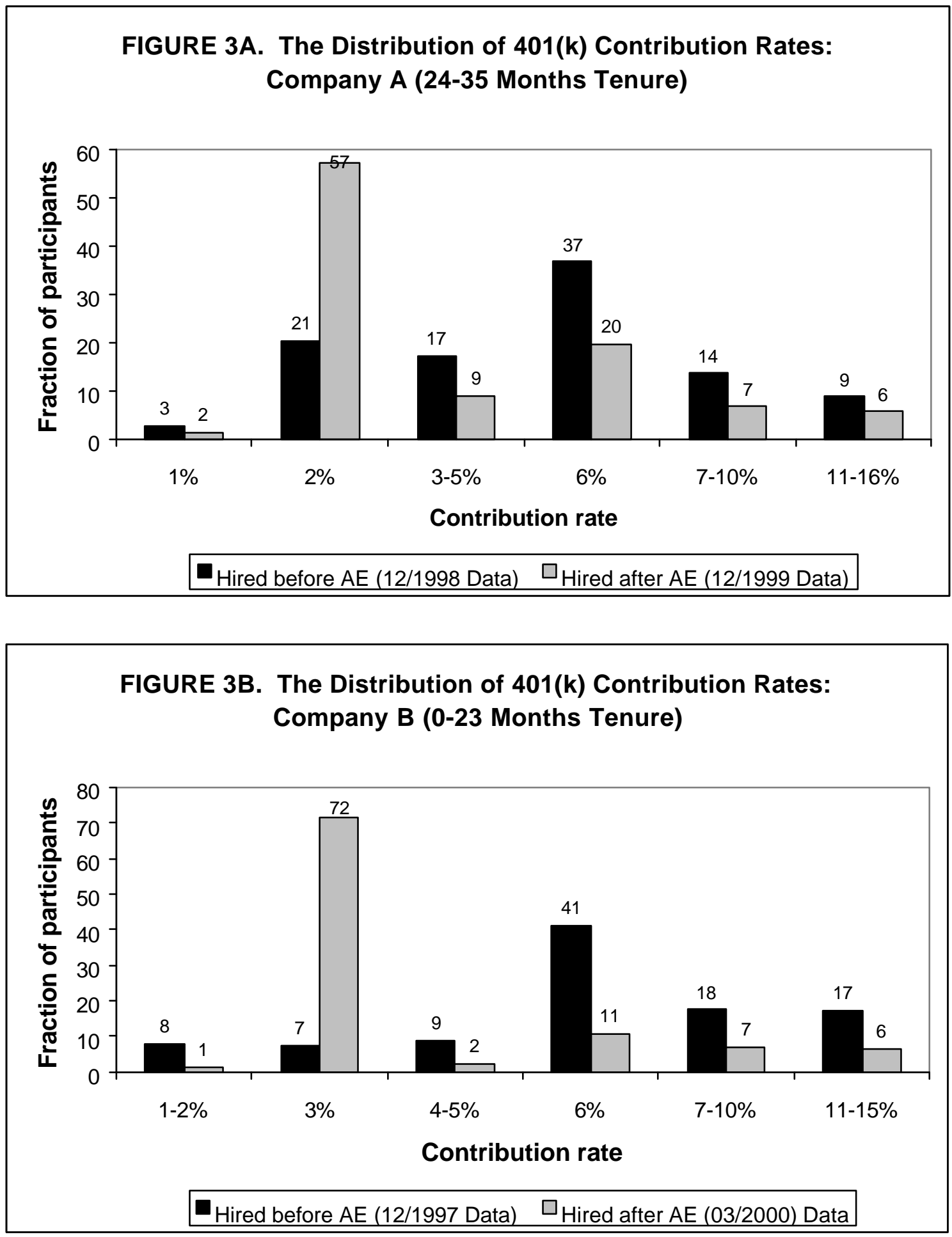


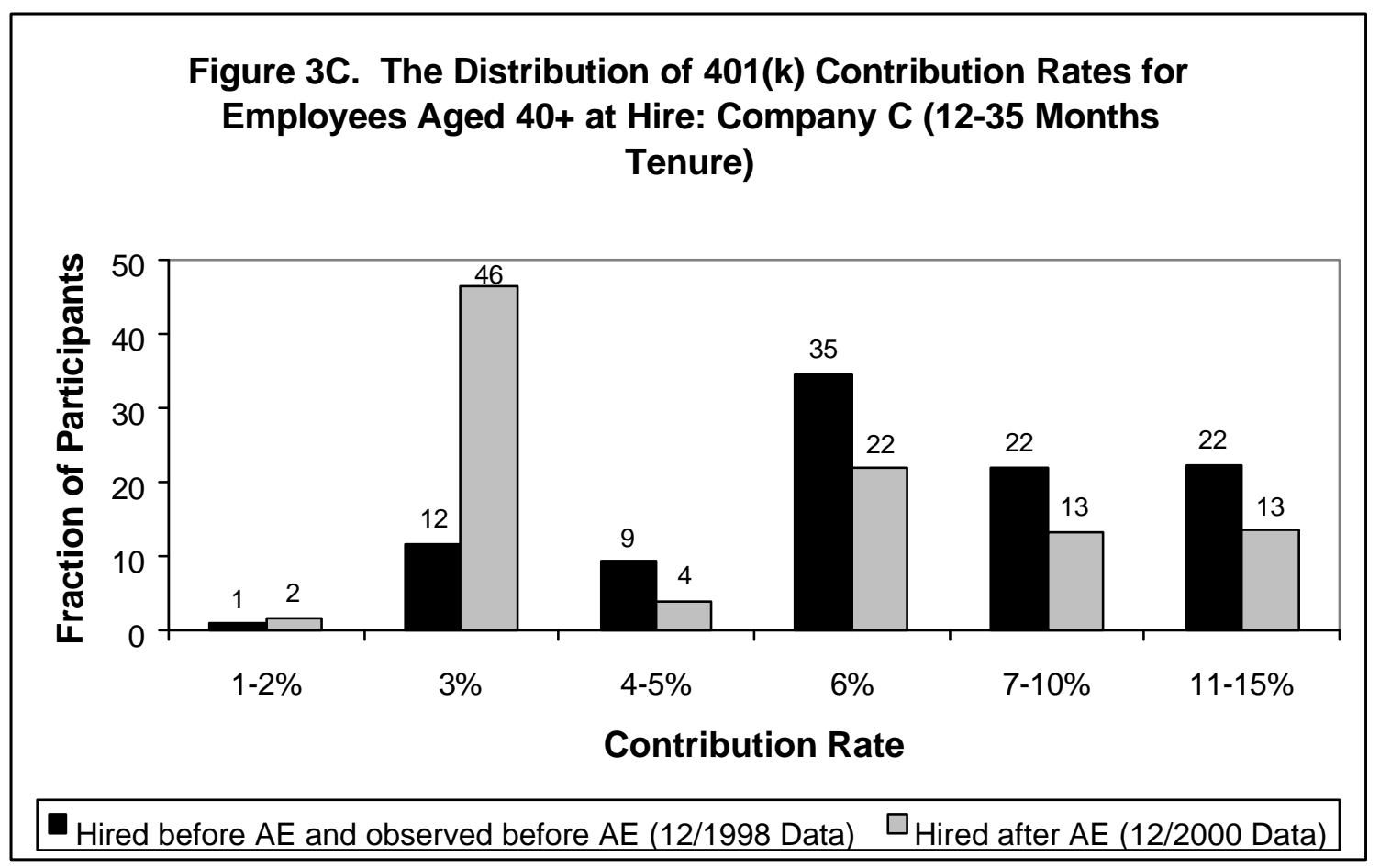



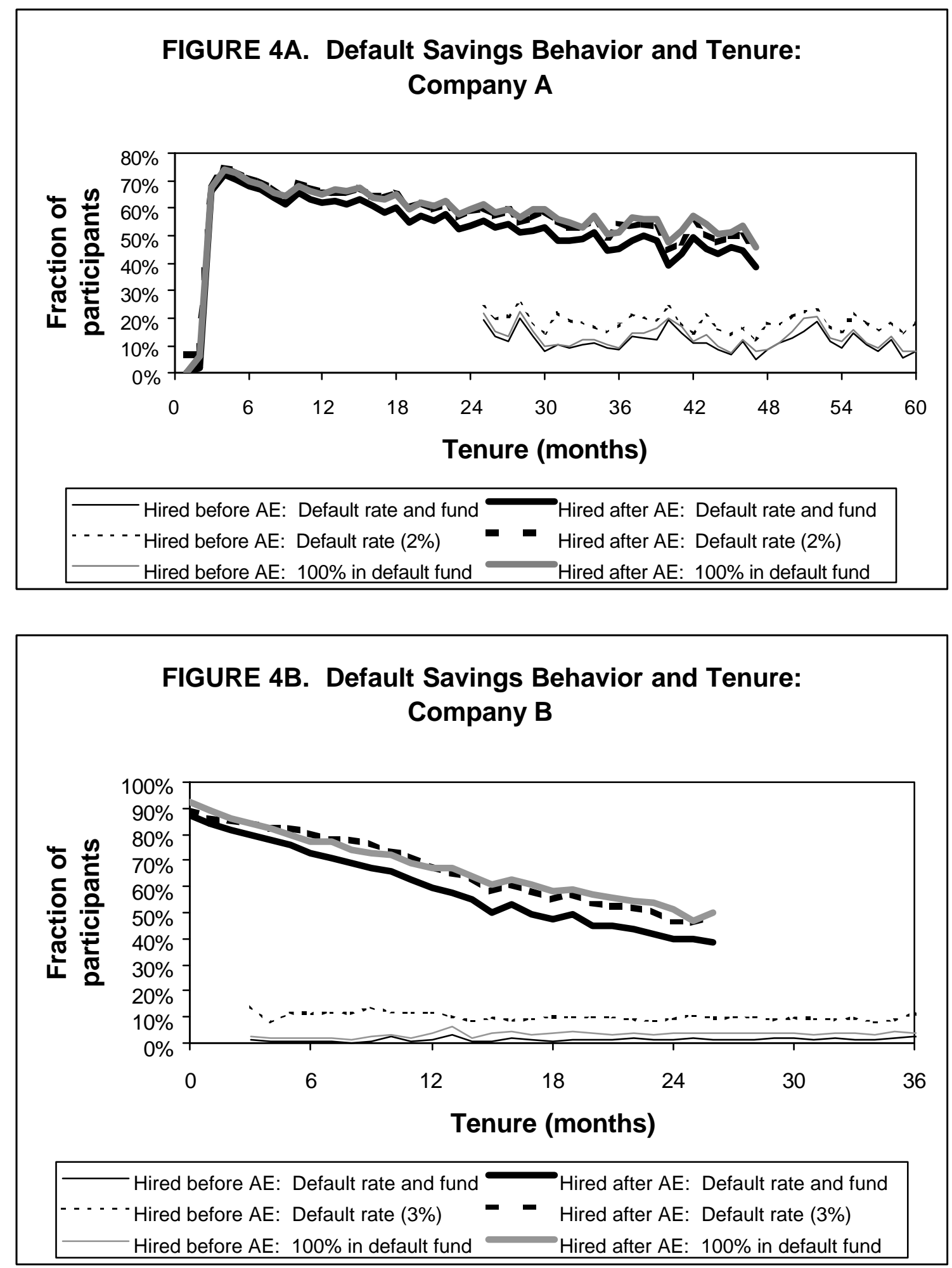


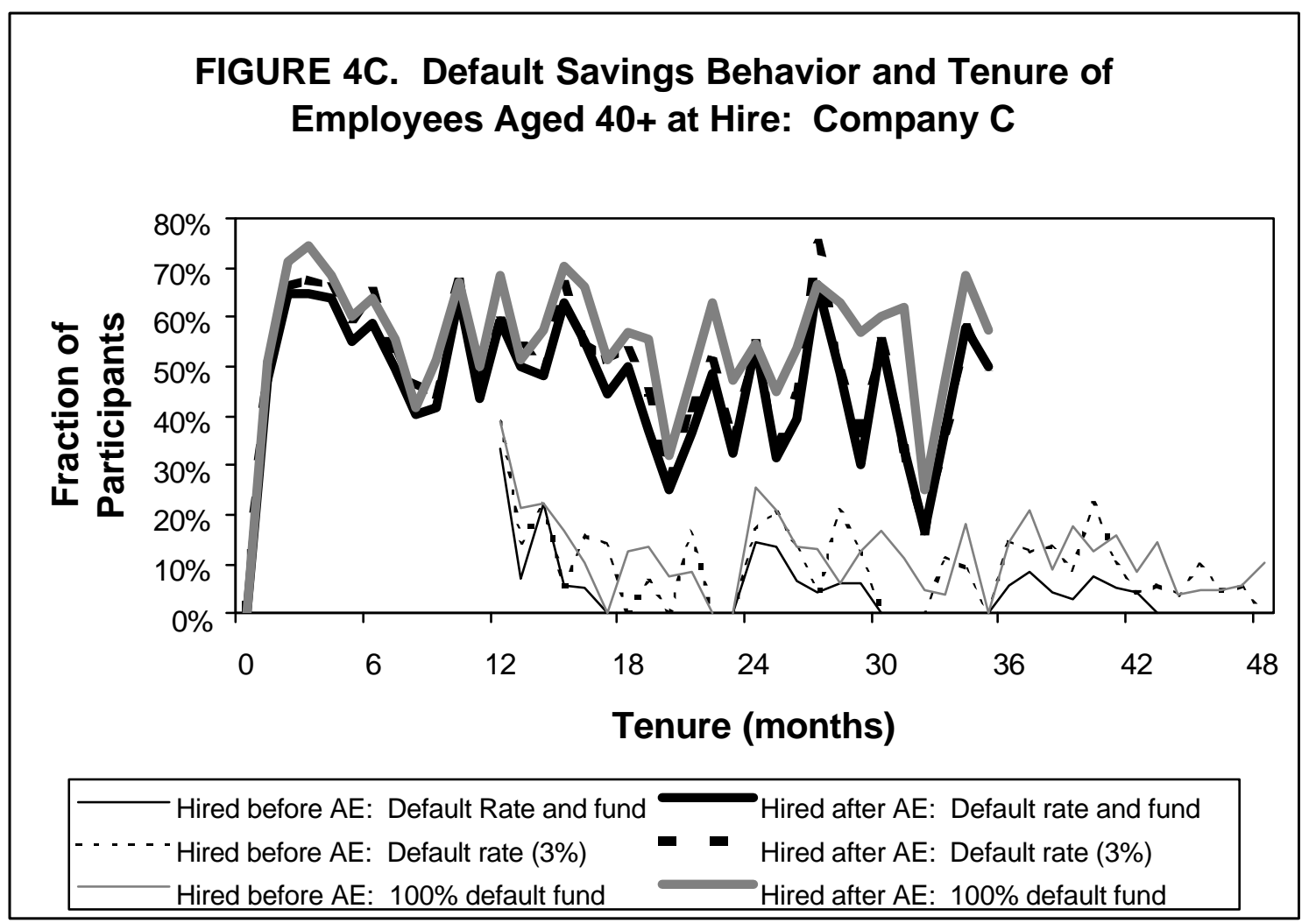




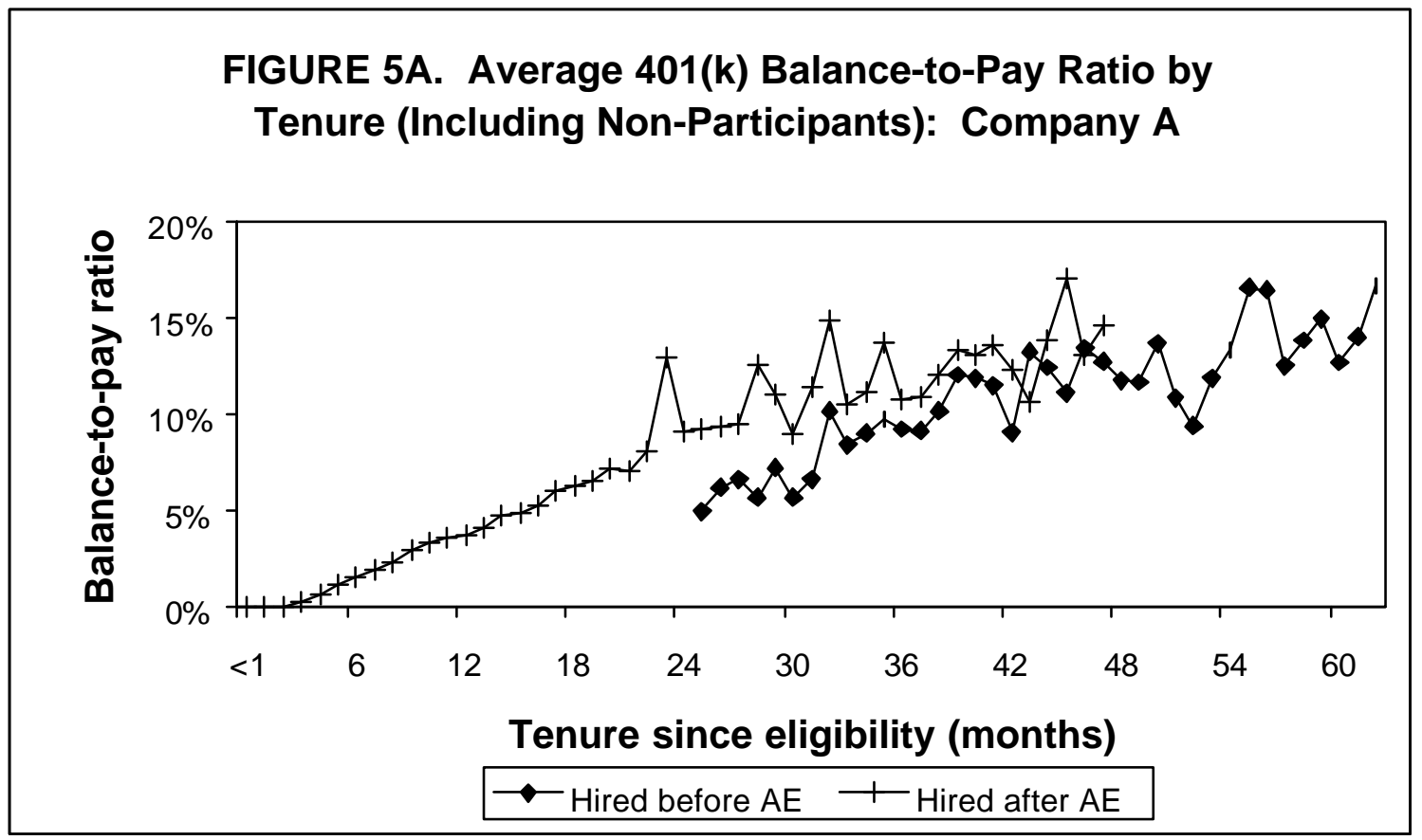

FIGURE 5B. Average 401(k) Balance-to-Pay Ratio by Tenure (Including Non-Participants): Company B

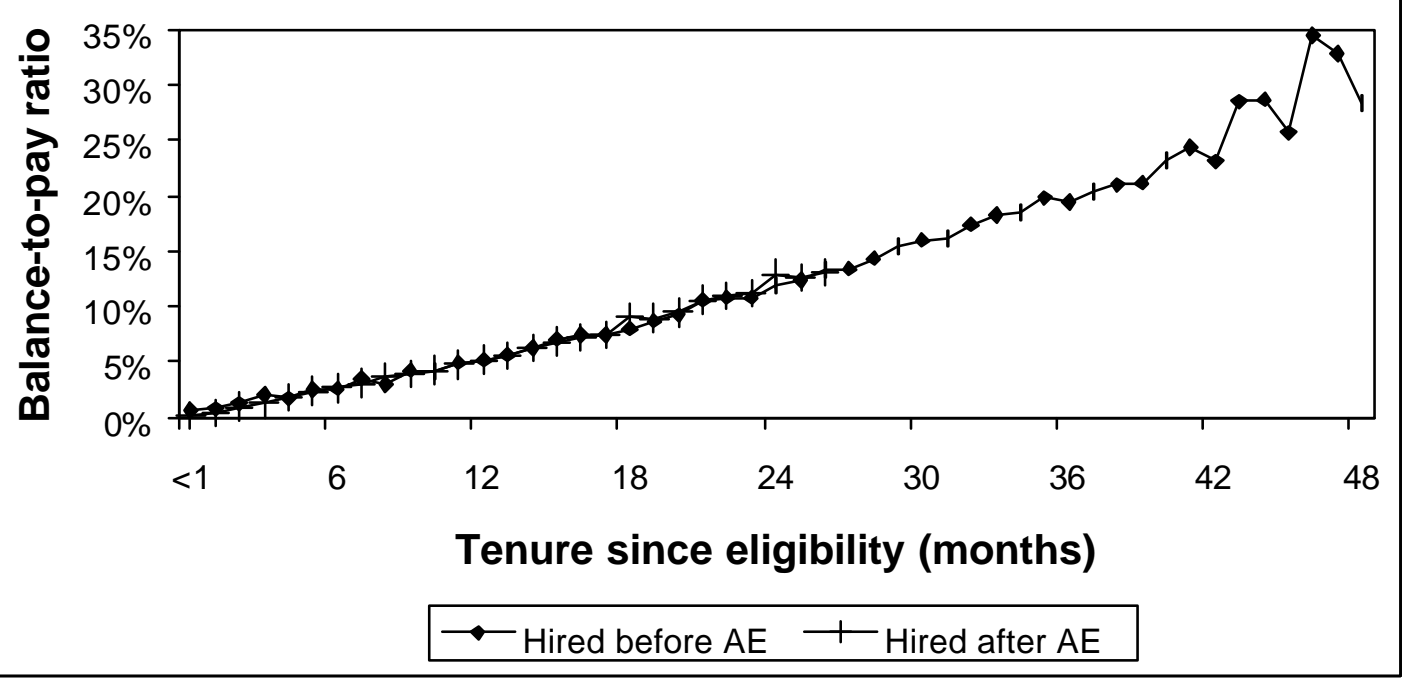


FIGURE 6A. The Distribution of the 401(k) Balance-to-Pay Ratio by Tenure: Company A
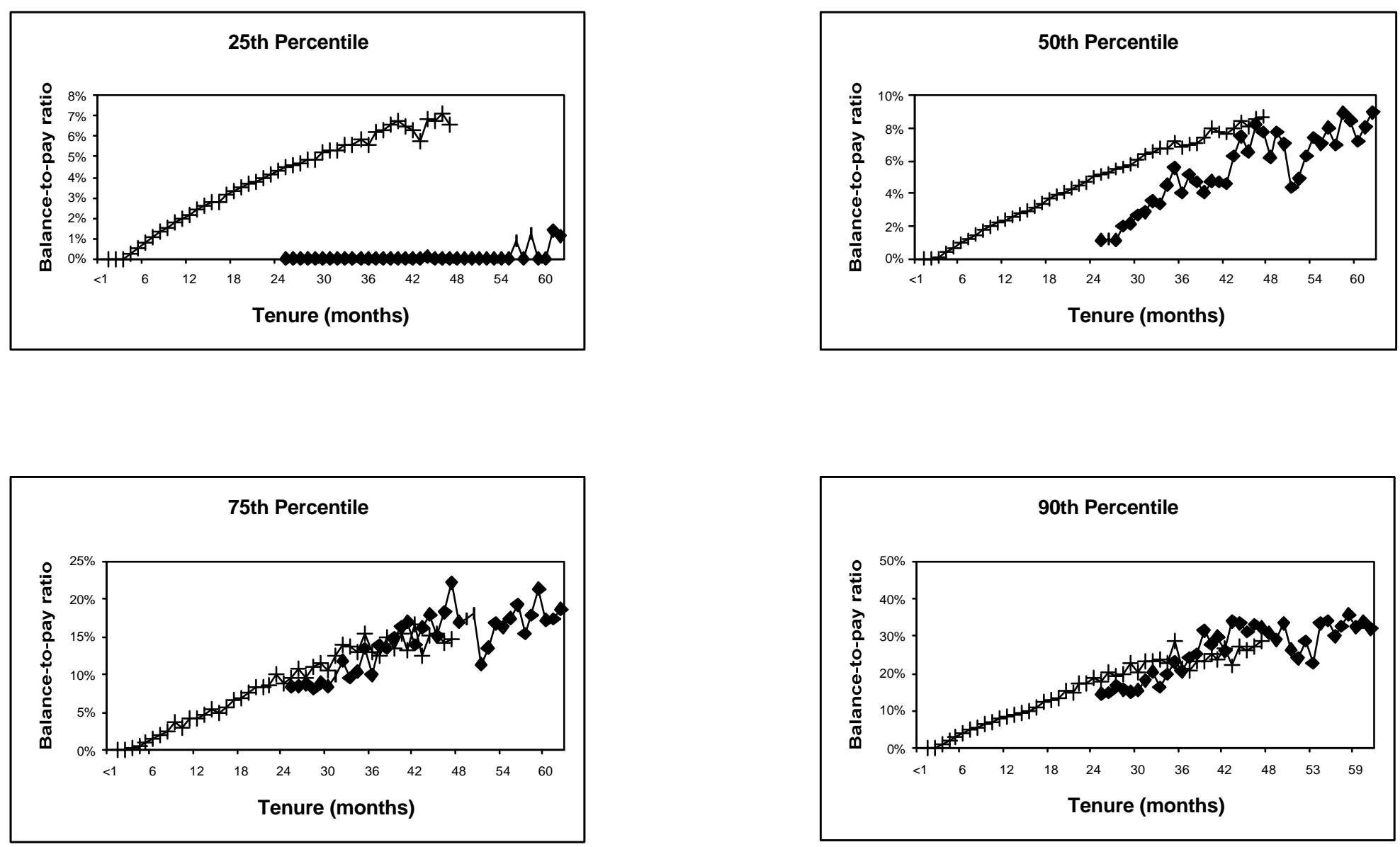

Hired before AE $\quad$ - Hired after AE 
FIGURE 6B. The Distribution of the 401(k) Balance-to-Pay Ratio by Tenure: Company B
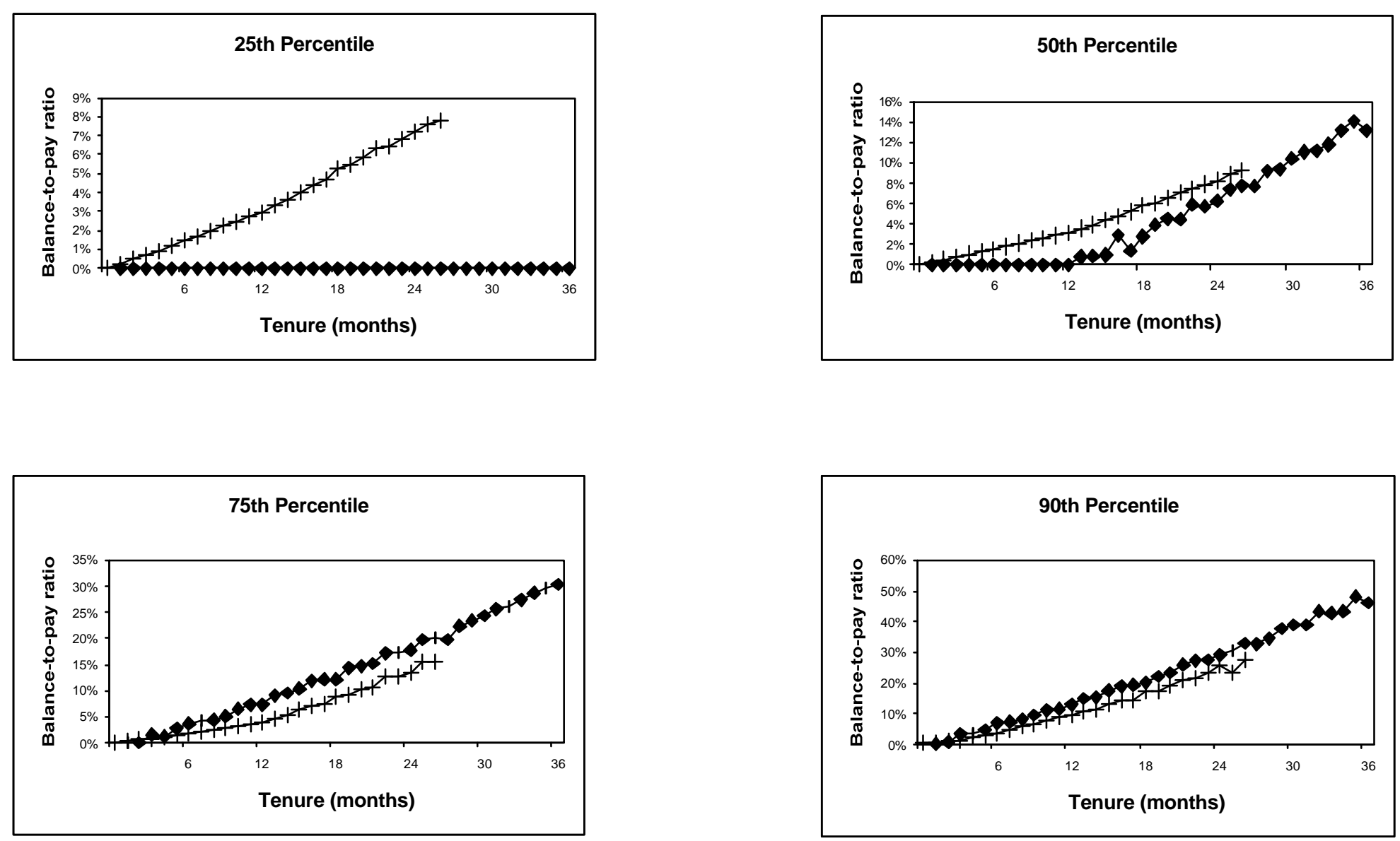

Hired before $A E \quad$ - Hired after $A E$ 

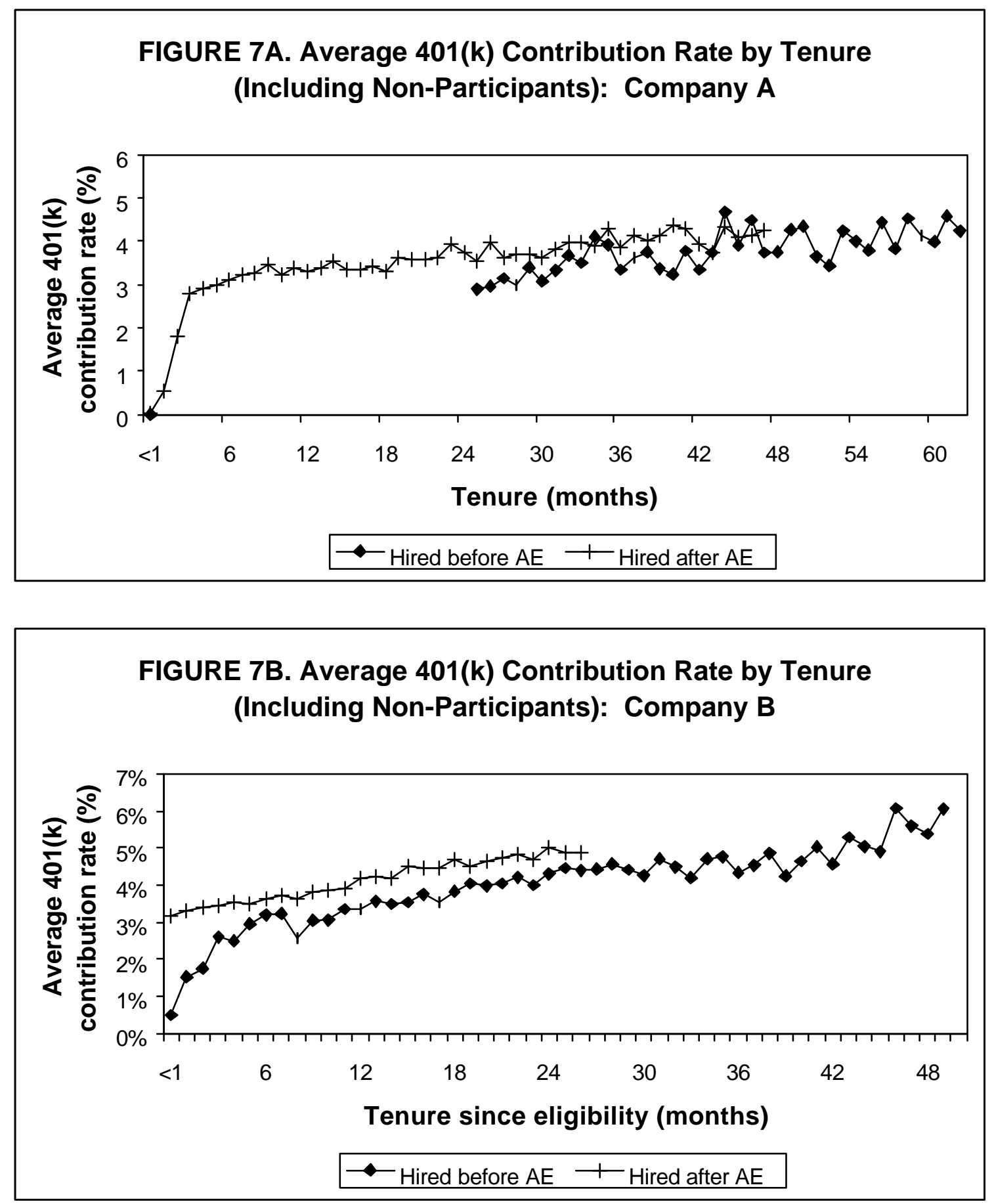